\title{
Composition-Volume Changes during Metasomatic Alteration of Pan African Andesitic Volcanic Rocks at Gabal El Dokhan Area, Northeastern Desert, Egypt.
}

\author{
Ezz El Din A. Khalaf \\ Geology Department, Faculty of Science, \\ Cairo University, Giza, Egypt
}

Received: 7/12/1998 Revised: 9/4/2000 Accepted: 26/6/2000

Abstract. Metasomatic alterations of the Late Proterozoic andesites at Gabal El Dokhan area display obvious change in mineralogical and chemical composition, if compared with the least altered andesitic rock types (assumed protoliths). These altered andesitic rocks have been metamorphosed to lower-middle greenschist facies typified by biotite-actinolite-chlorite-albite-epidote-quartz-opaque minerals/sphene assemblages. Five alteration facies have been recognized: 1) Biotitization-silicification, 2) Sericitization-silicification, 3) Albitizationsilicification, 4) Epidotization-silicification, and 5) Chloritization.

The biotitized-silicified rock types are enriched in K-Rb-Ba-FTSM and depleted in LREE relative to the least altered rock. The sericitized-silicified rock types are significantly enriched in $\mathrm{K}-\mathrm{Rb}-\mathrm{Ba}$ and depleted in FTSM and LREE. The albitized-silicified rock types are strongly enriched in $\mathrm{Na}$ and depleted in LILE and LREE relative to the least altered rock types. The epidotized-silicified rock types are enriched in $\mathrm{Ca}-\mathrm{Cu}-\mathrm{Pb}$ and depleted in LILE and LREE. The chloritized rock types exhibit relative enrichment in $\mathrm{Mg}, \mathrm{FTSM}, \mathrm{Zn}-\mathrm{As}-\mathrm{Pb}$ and depletion in LILE and LREE.

The behavior of the Ti, $\mathrm{Al}, \mathrm{Fe}_{\mathrm{t}}, \mathrm{P}$, and most HFS elements during biotitization, sericitization, albitization, epidotization and chloritization suggests that they were inert during metasomatic modification of the andesites. Mass balance calculations suggest that volume change was restricted between zero and up to $+20 \%$ for the altered upper andesites and -25 and up to $+25 \%$ for the altered lower andesites during the different types of metasomatic facies. Elemental mobilities are interpreted in terms of the controlling mineral phases and the possible nature of the various metasomatising fluids. 


\section{Introduction}

During hydrothermal system, weathering, metasomatism and metamorphism, emplacement and crystallization of magmas, chemical components are redistributed among fluid and solid phases. Metasomatism has played an important role, resulting in considerable elements redistribution and reequilibration of the major rock-forming minerals. The actual gains and losses that take place in metasomatic alterations cannot be obtained without knowledge of the relationship between composition and volume changes that accompany the process. The importance of composition-volume relationships has been recognized by Poldervaart (1953), Turner and Verhoogen (1960), and Bogolepov (1963). In the study of metasomatically altered rocks, the immediate questions concern the nature of the original rock and gains and losses of components necessary to produce the altered rock. By careful consideration of the petrology and field setting of an area, one may be able to determine a "least- altered equivalent". This is probably the major step in unraveling the alteration process. Assuming that this has been done, one has to consider next the basis for determining the relative gains and losses that gave rise to the altered rock. In some cases the assumption of constant volume seems to work, in some, constant alumina, and in other cases, other components seem to have been relatively immobile (Grant, 1986). The procedure used in this paper demonstrates how gains and losses may be calculated using the actual chemical analysis.

Gabal El Dokhan area has been the subject of several studies since early historic Roman time. Several authors described the Dokhan volcanics as post tectonic, almost unmetamorphosed volcanic rocks, represented mainly by andesites, porphyrites, rhyodacites, pyroclastics and Imperial porphyries (Akaad and Noweir, 1969; and El-Ramly, 1972). Others suggested that Dokhan volcanics are propylitized by post magmatic regional and thermal metasomatic processes (Gobrial and Lotfi, 1967, Basta et al. 1979; and Khalaf, 1994).

The studies of metasomatic alterations are important because they provide information concerning the physical and chemical properties of the ore-forming fluids, and because they characterize the ore-related alteration signatures which may be useful in mineral exploration. Despite the mineralogical and geochemical changes that accompany such metasomatic alteration, many interpretations of chemical fluxes have assumed that rock volume is conserved (Riverin and Hodgson, 1980, and Gibson et al. 1983). Most arguments for conservation of volume are based on good textural preservation in the altered rocks, but volume changes are hard to assess in rocks with fine grained mesostases (Lesher et al. 1986). In view of the significant mineralogical changes observed in the metasomatic altered volcanics, the assumptions of constant volume metasomatism might not be necessarily valid. 
The principal objectives of this study are: i) to assess the nature of chemical mobility during the hydrothermal alteration of Dokhan volcanic rocks; ii) to place constraints on volume changes during such alteration; iii) to identify those elements, which remain immobile during such metasomatism. These computations have the advantage over binary variation diagrams in that they are capable of comparing individual analyses in a metasomatic environment with a common parent. They also reveal the interrelationships between and within groups of elements and their relative mobilities.

\section{Geological Setting}

The Dokhan area lies to the northwest of Hurghada on the Red Sea coast. It is delimited by latitudes $27^{\circ} 17^{\prime} 34^{\prime \prime}-27^{\circ} 19^{\prime} 59^{\prime \prime} \mathrm{N}$ and longitudes $33^{\circ} 12^{\prime} 30^{\prime \prime}$ $33^{\circ} 15^{\prime} 00^{\prime \prime}$ E. The studied area is mainly covered by volcanic sequences, Hammamat facies sediments, intrusive rocks and younger rock dykes (Fig.1). The volcanic rocks are unconformably overlain by Hammamat facies sediments especially at the southern side along Gabal Umm Tawat. These volcanosedimentary rocks are intruded by different suites of intrusive rocks including gabbroic and granitic rocks besides bimodal mafic-felsic rock dykes and ptygmatic folded quartz veins.

The studied volcanics at Gabal El Dokhan are part of Late Proterozoic volcanic series of Arabo-Nubian massif which is known in the Northern Eastern Desert as Dokhan volcanics according to their type locality Gabal El Dokhan (1661 $\mathrm{m}$ above sea level). The Dokhan volcanics represent an important stratigraphic unit within the Egyptian basement complex. These volcanics are essentially composed of andesites and andesitic pyroclastics with subordinate basaltic andesites conformably overlain by eruptions of rhyolites and ash flow tuffs. The andesites are massive, unfoliated and well exposed along a large number of wadies draining Gabal El Dokhan. Interbedded with the andesites are banded tuffs, volcanic breccias and agglomerates.

Detailed field mapping of the Dokhan volcanics revealed that the andesites and associated pyroclastics can be divided into two different volcanic sequences, termed lower (or older) and upper (or younger) andesitic rock sequences (Khalaf, 1994). The lower (old) eruptions are mainly composed of amphibole-free andesites and pyroclastics as well as minor basaltic andesites, which are exposed along wadies Sidri, Umm Lang and El-Atrash. The upper (young) eruptions are essentially composed of amphibole-rich andesites and pyroclastics including the famous Imperial porphyries exposed only along wadi Maamal, where they cut across the early andesitic sequences in the form of volcanic plugs and sheets. Occasionally, these Dokhan volcanics are affected by shear zones, resulting in schistose pencil structure trending generally $\mathrm{N} 25^{\circ} \mathrm{W}$ 


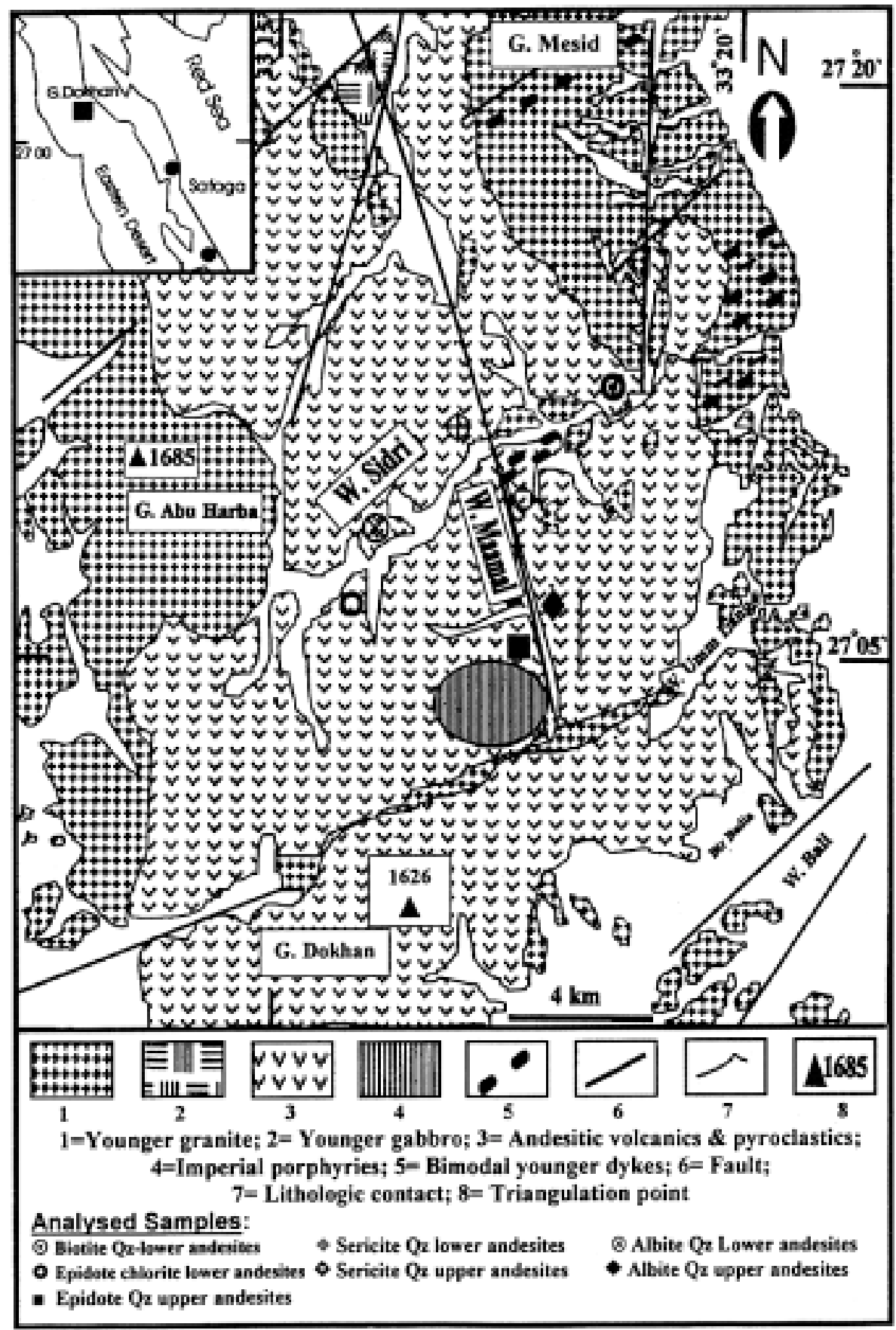

FIG. 1. Simplified geological map of the study area. 
and dipping $57^{\circ} \mathrm{SE}$. Greenschist metamorphism has modified the mineralogy and texture of these volcanics especially along shear and fault zones. The highly sheared and altered rock types have been metamorphosed to lower-middle greenschist facies typified by chlorite-actinolite-albite-epidote-quartz-opaque minerals/sphene assemblages, even though the preservation of volcanic textures and lack of any penetrative fabric indicate that the degree of deformation is minimal. The nature and degree of alteration varies from one rock group to another and may be overprinted by granitic contact metamorphic events. Along the granitic contacts, these andesites are granulated, hybridized, mylonitized, thermally metamorphosed, with hornfelsic, decussate and granoblastic fabric and display intensive silicification, biotitization, sericitization and pigmentation, with red feldspar phenocrysts dispersed in aphanitic groundmass. Generally, the propylitic alteration (epidote, actinolite, chlorite, and quartz) is the most widespread facies through the entire volcanic sequences, while the phyllic (sericite, quartz) and potassic alterations (biotite, orthoclase, sericite, and quartz) are dominant and localized along the contacts of granitic rocks and quartz veins. Silicification typifies the Dokhan volcanics on a regional scale, related spatially and temporarily to the intrusion of granitic rocks and hydrothermal solutions. It manifests itself as irregular white patches and as halos mantling amygdales and fractures. This alteration is pervasive and characteristically patchy; the end result is a heterogeneous-looking rocks, with dark green areas of weakly silicified andesites (weathered brown) adjacent to and gradational with irregular area of white, strongly silicified andesite. Hydrothermal fluids associated with volcanic exhalation and granitic rocks were channeled and discharged by volcanic faults that breached the volcanics and produced different types of alterations. All alteration types are found within the volcanic sequences. The highly metasomatised rock types cannot be recognized in the field as the altered rocks look entirely fresh and undistinguishable from the original ones. The alteration, however, affects the mineralogy of the rocks as seen under the microscope and is most conspicuous in chemical composition.

\section{Petrography}

Based on the field and petrographic criteria, two andesitic rock types have been recognized. Younger amphibole-rich andesites cut older amphibole-free andesites and associated pyroclastics. The petrographic characteristics of the least-altered andesites from the two volcanic sequences and corresponding metasomatised rock types are described below.

\section{Least-Altered Andesites}

The least-altered lower andesites consist primarily of glomeroporhyritic plagioclase feldspar $\left(\mathrm{An}_{37}\right)$, clinopyroxene, opaque minerals, and accessory apatite 
with secondary quartz, sericite, and epidote set in a fine grained groundmass displaying trachytic and hyalopilitic textures. Plagioclase feldspars ( $46 \%$ by mode) occur as zoned and twinned subhedral crystals. They suffer slight kaolinization and sericitization. Clinopyroxene ( $13 \%$ by mode) displays pale green, faint pleochroism and slight alteration to uralitic hornblende, accompanied by opaque minerals especially along cleavage and crystal borders.

The least-altered upper andesites encompass essentially zoned plagioclase phenocrysts $\left(\mathrm{An}_{31}\right)$, green and brown hornblende, brown apatite with quartz, Mn-epidote (piemontite), opaque minerals and sphene as xenocrysts embedded in a fine grained groundmass exhibiting subfluidal and felty texture. Plagioclase crystals (30\% by mode) form cumuloporphyritic clots and subophitic texture with hornblende crystals. Oscillatory zoning is a common optical feature within the plagioclase crystals. The plagioclase phenocrysts suffer a slight degree of alteration through sericitization. Hornblende glomeroporphyritic crystals $(18 \%$ by mode) occur as euhedral to subhedral fresh crystals of green and brown types. They display twinning and strong pleochroism. Microprobe analysis shows that the most dominant hornblende crystal types are magnesio hornblende (green color) which grade to magnesio hastingsitic hornblende (brown color) especially along crystal borders. From the above description, it is clear that the leastaltered lower and upper andesites are fresh rocks and are petrographically characterized by: i) the absence of schistose texture; ii) the absence of veins; iii) the clean and fresh appearance of phenocrysts; iv) the paucity of opaque minerals in the groundmass.

\section{Biotitized-Silicified Andesites}

The biotitized-silicified andesites have coarse porphyritic texture with dominant plagioclase, actinolite and brown biotite as phenocrysts. Opaque minerals, sphene, quartz and apatite form xenocrysts. All the phenocrysts are set in quartzofeldspathic groundmass. The plagioclase forms glomeroporphyritic clots and suffers slight to complete alteration through kaolinization, sericitization and epidotization. Plagioclase phenocrysts have dusty and inclusion-rich core, mainly of opaque minerals, glass and quartz displaying sieve texture. Occasionally, plagioclases are mantled by orthoclase (Fig.2A). Shreddy biotite occurs as anhedral xenocrysts, displaying strong pleochroism and replaces the groundmass (Fig.2B). The groundmass consists essentially of feldspar microlites, recrystallized quartz granoblasts, actinolite, biotite, opaque minerals, sphene and apatite with granoblastic texture. In strongly silicified andesitic rock types, quartz xenocrysts concentrate preferentially in the empty spaces as pockets, amygdales and linings of vesicles. 


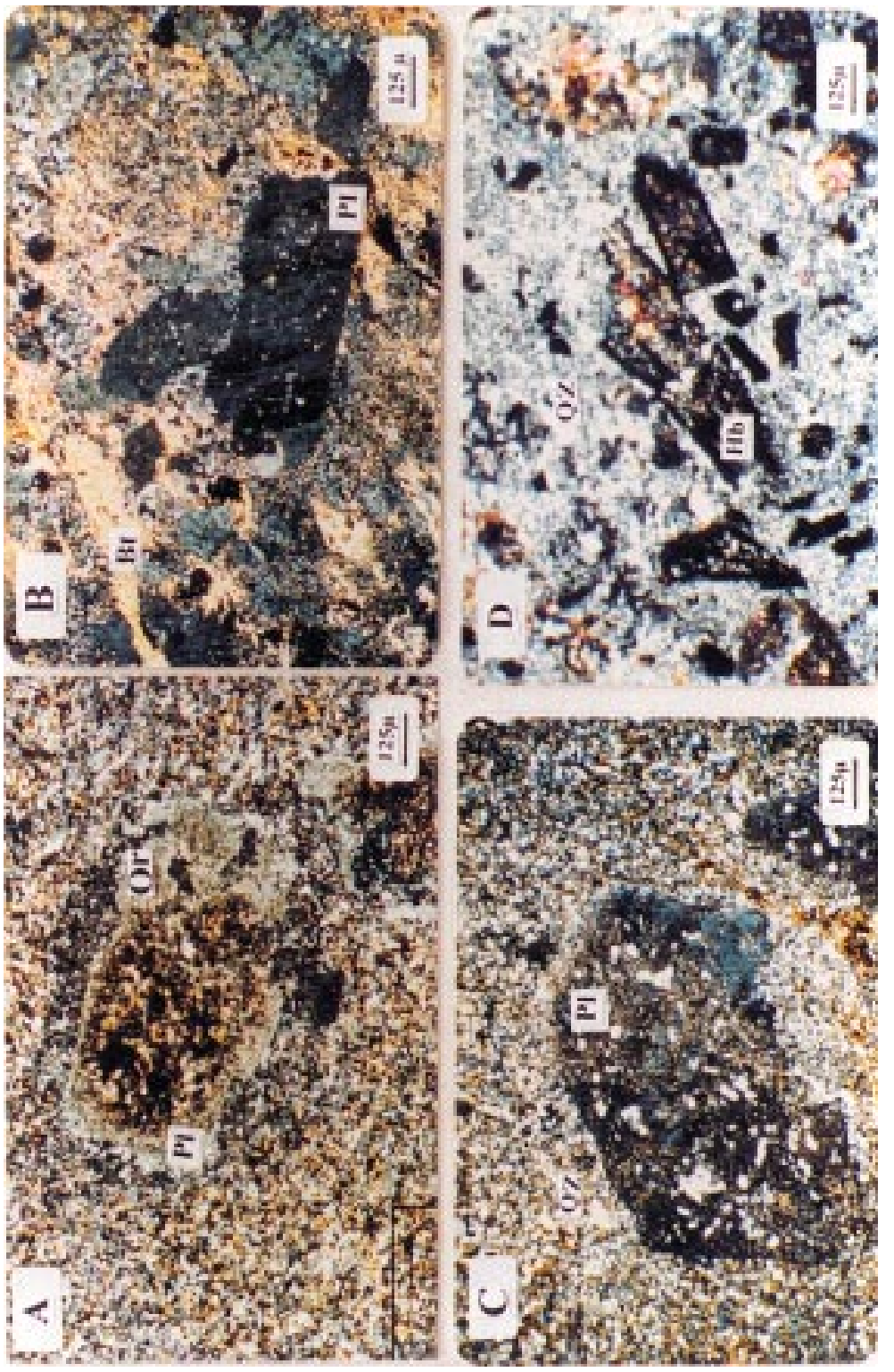




\section{Sericitized-Silicified Andesites}

The sericitized-silicified lower andesites consist essentially of completely sericitized and kaolinitized plagioclase with seriate porphyritic texture. Quartz xenocrysts and opaque minerals form the secondary minerals. Apatite is the most common accessory phase. The groundmass encompasses the same phases as the phenocrysts and occasionally interstitial glass. The sericitized-silicified upper andesites contain sericitized plagioclase glomeroporphyritic clots and chloritized hornblende with secondary quartz, Mn-epidote (piemontite) and opaque minerals. All the phenocrysts are set in a fine-grained groundmass highly enriched in sericite and quartz granoblastic.

\section{Albitized-Silicified Andesites}

The albitized-silicified lower andesites are porphyritic and contain primary plagioclase, chloritized clinopyroxene with secondary quartz, epidote and opaque minerals. They are set in a devitrified fine-grained groundmass. The plagioclase $\left(\mathrm{An}_{15}\right)$ suffers different degrees of kaolinization, sericitization and epidotization. Occasionally, epidotization is complete, so that epidote (mainly zoisite) replaces most of the plagioclase crystals especially at the crystal cores. Plagioclases encloses granoblastic quartz and opaque minerals as poikilitic inclusions giving spongy like appearance (Fig.2C). The groundmass is crypto to microcrystalline and contains quartz xenocrysts, sodic plagioclase laths, opaque minerals, epidote and recrystallized biotite flakes. The albitized-silicified upper andesites consist essentially of epidotized plagioclase glomeroporphyritic clots and highly resorbed hornblende with well developed opacite mantles (Fig. 2D). Quartz, piemontite, opaque minerals and sphene form secondary minerals. The groundmass is tuffaceous in nature and contains albitized plagioclase microlites, quartz-epidote filled amygdales and resorbed hornblende with felted to microlitic texture.

\section{Epidotized-Actinolitized Andesites}

The epidotized-actinolitized lower andesites contain completely epidotized plagioclase clots and actinolite with secondary quartz, chlorite, carbonate and opaque minerals set in quartzofeldspathic fine grained groundmass with amygdaloidal and granoblastic texture. The epidotized-silicified upper andesites encompass epidotized plagioclase, actinolite with secondary quartz, opaque minerals and sphene. The groundmass consists of albitic plagioclase microlites, epidote, quartz and carbonate-chlorite filled amygdales with felted to fluidal texture. 


\section{Chloritized Andesites}

The chloritized andesites have a texture ranging from almost aphyric to strongly porphyritic with dominant phenocrysts of epidotized plagioclase and chloritized clinopyroxene. Quartz, epidote, sphene and chlorite form the secondary minerals. All the phenocrysts are set in a devitrified glassy groundmass with hyaloplitic texture.

The petrographic investigations therefore indicate that chloritization is an early alteration that was operative in the lower andesites prior to extrusion of the upper andesites. Sericitization and albitization postdates the chloritization. Silicification is a later alteration that affects all the stratigraphic units and is superimposed on previously mentioned alterations.

\section{Geochemistry}

Major and trace elements of the rock samples were determined by X-ray fluorescence (XRF) at the Institute of Mineralogy and Petrology, Bonn University, Germany, on a Phillips 1480 automated X-ray fluorescence spectrometer. The program used for the calculation of element concentration was Oxiquant distributed by Phillips for their XRF spectrometry. The chemical analyses are subjected to certain errors. The major element determinations have certain errors up to \pm 2 rel.- $\%$; those of trace elements have up to \pm 8 rel.- $\%$ or even \pm 12 rel.- $\%$ in the case of REE.

For clarity and brevity of description, several of the elements analyzed in this study are grouped according to their geochemical characteristics namely; largeion lithophile elements (LILE: $\mathrm{K}, \mathrm{Rb}, \mathrm{Ba}, \mathrm{Sr}$ ), first transition series metals (FTSM: Mn, Fe, Zn, Sc, Ti, Cr, Ni), high field strength elements (HFSE: Y, Zr, $\mathrm{Nb}$ ) and light rare earth elements (LREE: La, Ce, Nd, Sm). The significance of these grouping and the geochemical characters of the altered rocks relative to the least altered rock types will be discussed further below.

The whole rock geochemical data for the 20 analyzed altered samples in addition to the least altered fresh rock samples (samples SIII.1 and MA.14) from the two Dokhan volcanic rock sequence are given in Table (1). The rock samples were collected from the various stratigraphic units and the alteration facies. The sample suite comprises biotitized-silicified andesites (S.26, SVI.1, and SVI.3), sericitized-silicified andesites (S.46 and SIII.3), albitized-silicified andesites (S.47, SII.5, and SD.1), epidotized and chloritized andesites (SIV.5 and SF.1 respectively) from the altered lower andesites. Besides, sericitized andesites (MA.16, MIII.4, and MV.2), albitized andesites (MV.12, MIV.8, and MIV.11) and epidotized andesites (MA.11, MV.4, MI.6, and MA.42) have been collected from the altered upper andesites. Sample locations are shown in Fig. (1). An- 


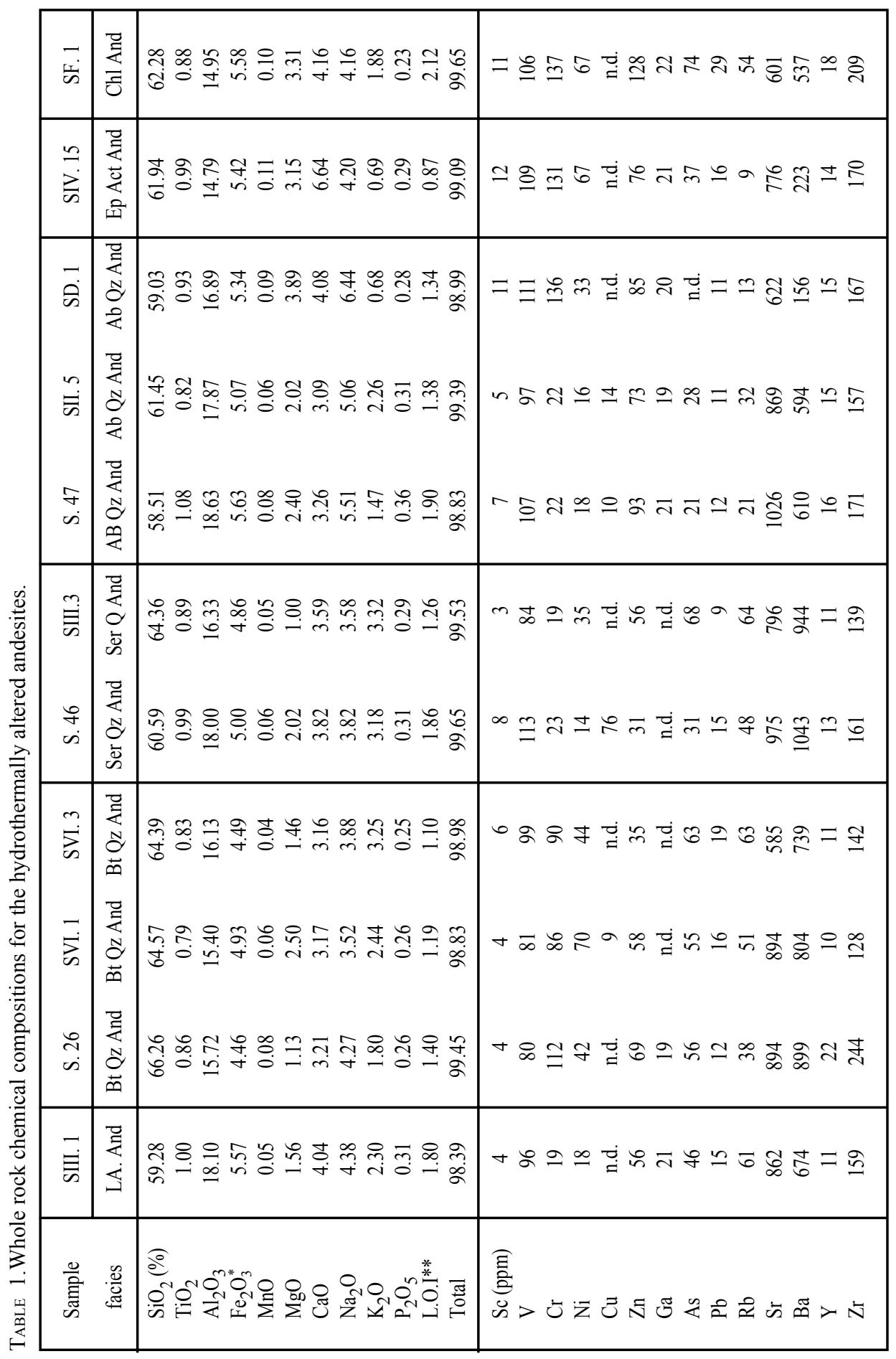


Composition-Volume Changes during Metasomatic Alteration of...

\begin{tabular}{|c|c|c|c|c|}
\hline ri & 焉 & 응 & $\begin{array}{l}\tilde{b} \\
i\end{array}$ & そ) \\
\hline$\stackrel{n}{i}$ & 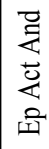 & a ষ্ণ ন & $\stackrel{n}{i}$ & 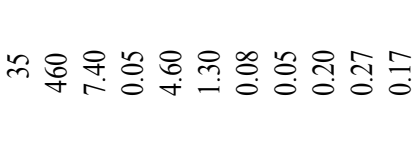 \\
\hline $\begin{array}{l}\stackrel{n}{E} \\
\stackrel{n}{\infty}\end{array}$ & 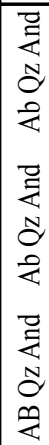 & 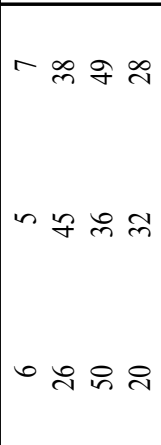 & 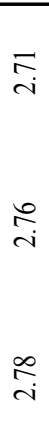 & 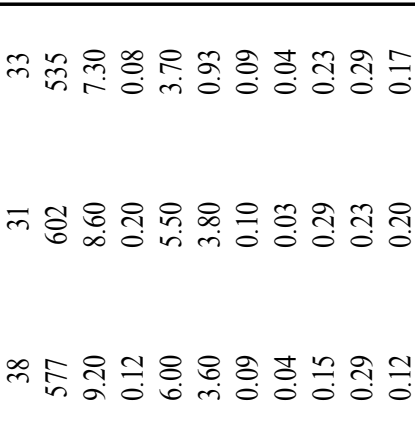 \\
\hline$\stackrel{?}{E}$ & 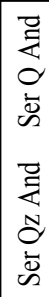 & $\begin{array}{l}-\forall i 尺 \\
-ষ ্ ণ \infty ~\end{array}$ & $\stackrel{\infty}{i}$ & 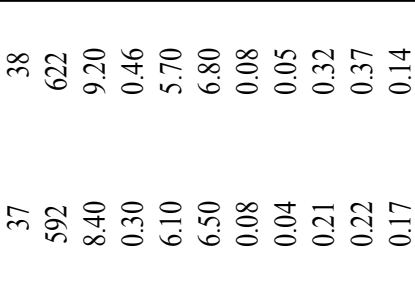 \\
\hline $\begin{array}{l}\text { m } \\
\dot{\infty} \\
\text { in } \\
\dot{\text { in }}\end{array}$ & 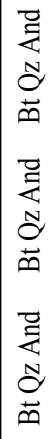 & 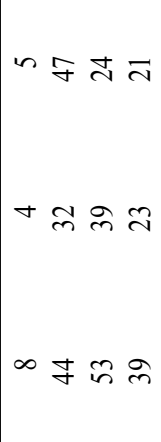 & $\stackrel{\widetilde{r}}{i}$ & 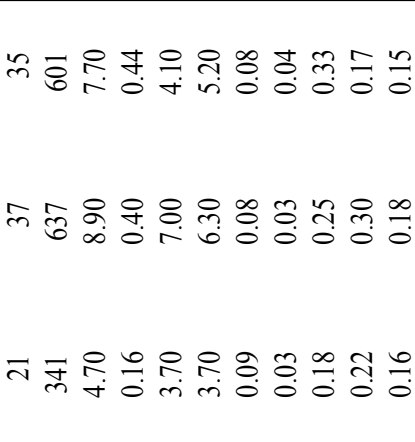 \\
\hline 砉 & $\begin{array}{l}\vec{U} \\
\dot{U} \\
\dot{J}\end{array}$ & -守古 & $\stackrel{\overbrace{}}{i}$ & 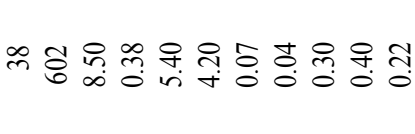 \\
\hline 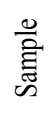 & $\frac{\mathscr{m}}{\mathscr{c}}$ & 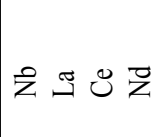 & نे & 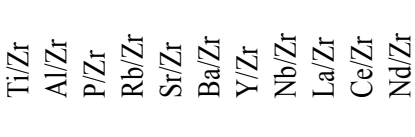 \\
\hline
\end{tabular}




\begin{tabular}{|c|c|c|c|}
\hline $\begin{array}{l}Z \\
\sum \\
\sum\end{array}$ & 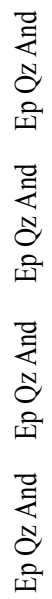 & 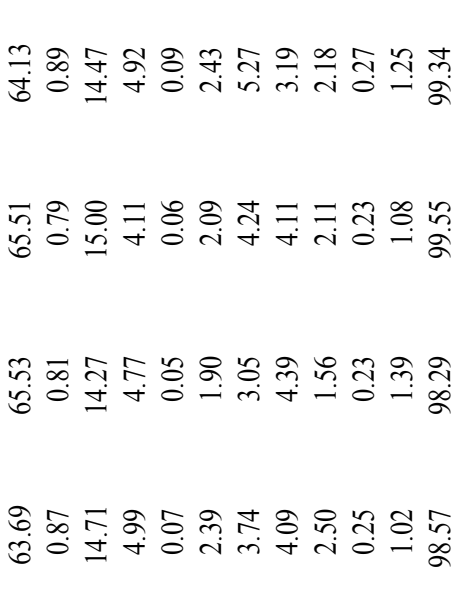 & 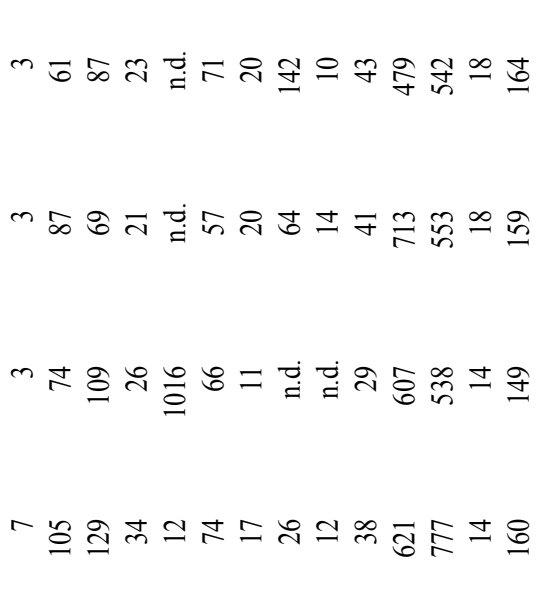 \\
\hline $\begin{array}{l}\exists \\
\dot{\Sigma} \\
\dot{\Sigma}\end{array}$ & 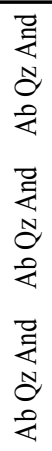 & 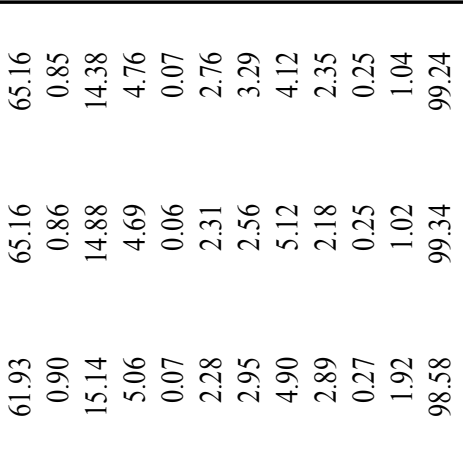 & 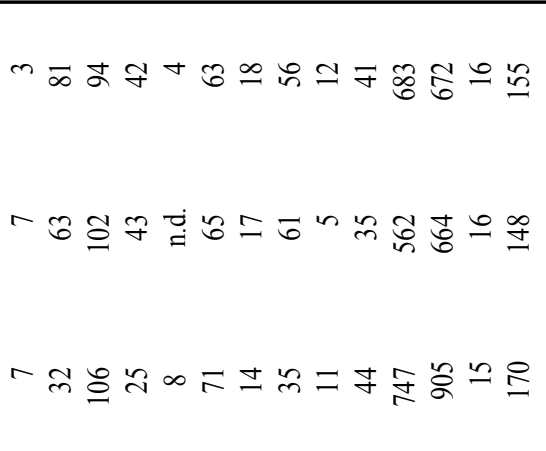 \\
\hline $\begin{array}{l}6 \\
\stackrel{\cos }{\Sigma}\end{array}$ & 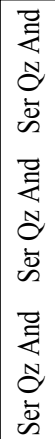 & 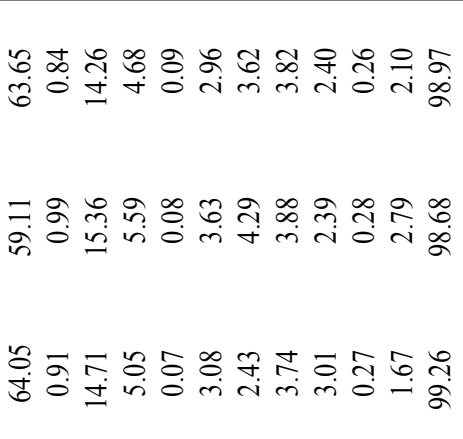 & 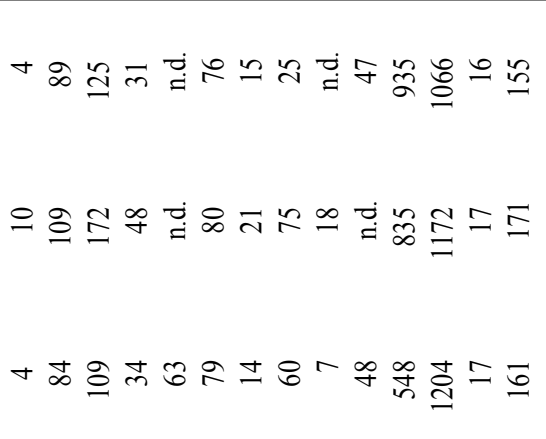 \\
\hline $\begin{array}{l}\text { さ } \\
\dot{\Delta}\end{array}$ & 兑 & 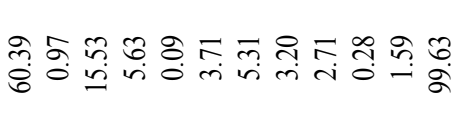 & 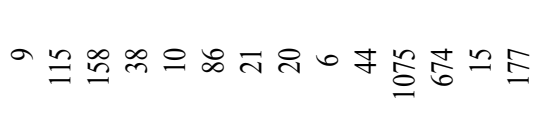 \\
\hline 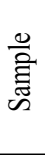 & $\frac{\mathscr{\omega}}{\stackrel{\mathscr{c}}{\pi}}$ & 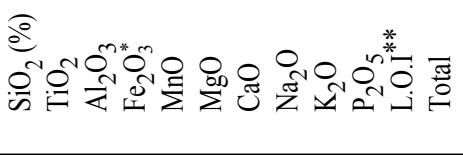 & 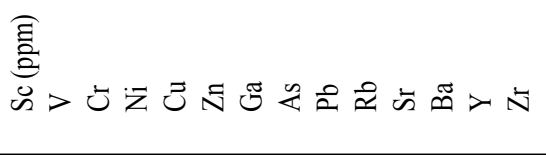 \\
\hline
\end{tabular}




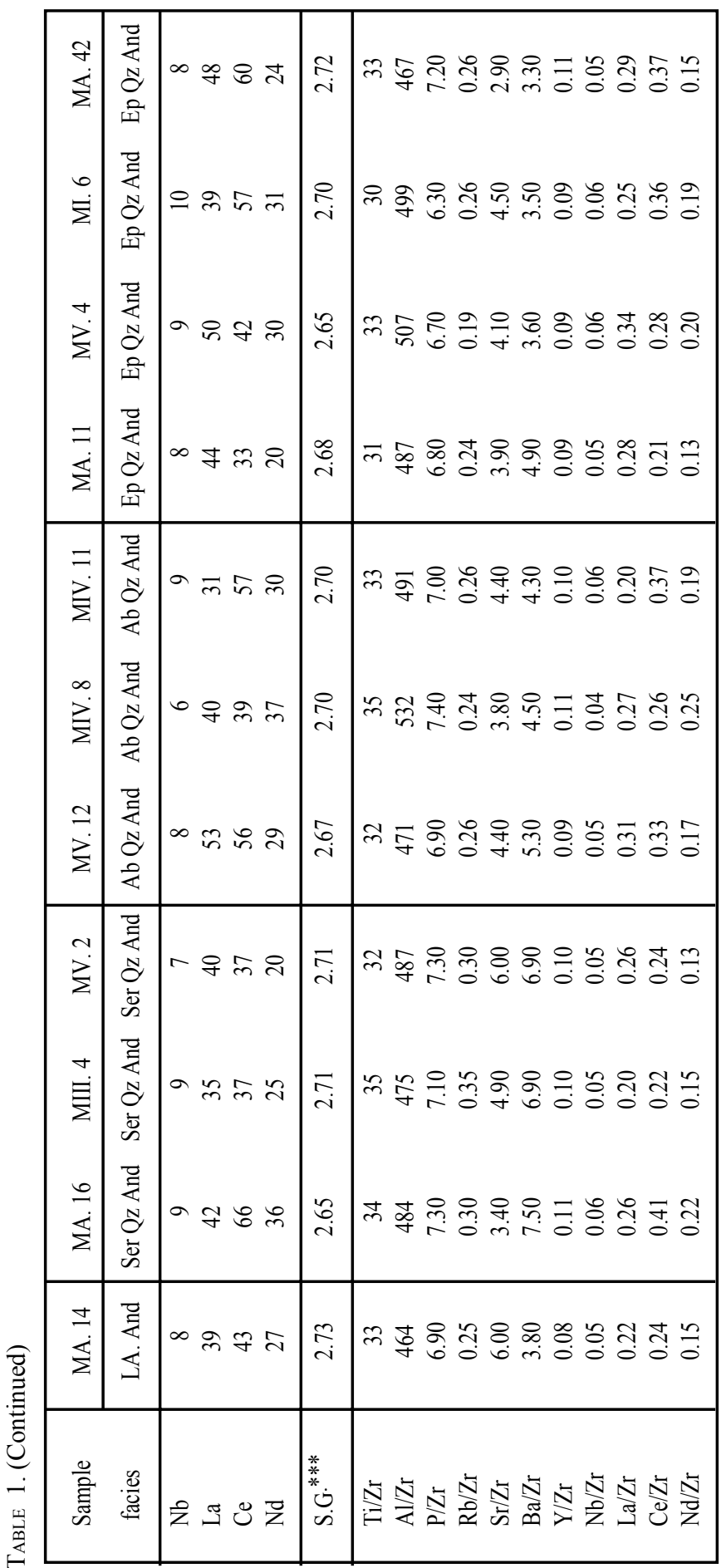

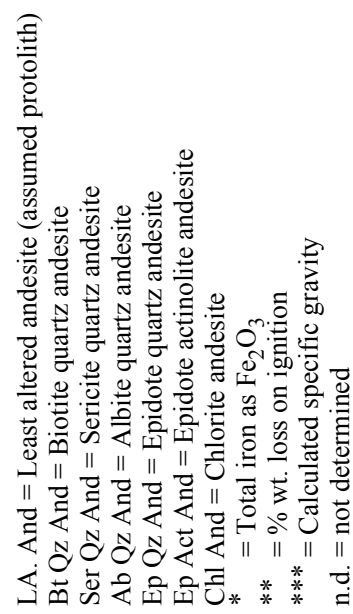


desite as used here is describes the rocks with intermediate silica content within the range $58.5-66 \% \mathrm{SiO}_{2}$.

The geochemical characteristics of the least-altered andesites (assumed protoliths) and the major alteration facies at Gabal El Dokhan (Fig.3) are described below. Alteration must also be evaluated before the petrogenesis and tectonic setting of ancient volcanic rocks can be interpreted (Condie, 1981; and Ludden et al. 1982). The superposition of some alteration types (e.g., sericitization on silicification) hampers resolution of the precise alteration signatures of some facies. Many of the rock samples, however, are dominated by one type of alteration, so they are discussed below in terms of that alteration.

\section{Least-Altered Andesites}

The least-altered rocks of Dokhan andesites (SIII.1, and MA.14) and their equivalent rock types in the studied area are classified as calc-alkaline volcanics on the basis of major element geochemistry (Irvine and Baragar,1971). The Dokhan andesites show pronounced enrichment in LILE and LREE and slight depletion in HFSE. The upper andesites are characterized by strong FTSM enrichment relative to the lower andesites. On the other hand, the chemistry of the lower andesites displays relative enrichment in total alkalies and LILE if compared with the upper andesites. The lower and upper andesites correspond to Andean type subduction-related magmatism; i.e. diagnostic ratios for arc lavas such as high LILE/LREE, LILE/HFSE and LREE/HFSE characterize the entire lava suites. Chondrite-normalized REE abundance for andesitic volcanics show LREE enrichment and low HREE pattern concentration with less negative Eu anomaly. Khalaf (1994) concluded that polybaric fractional crystallization with assimilation and /or magma mixing models can explain the evolution of the Dokhan volcanics at their type locality, Gabal El Dokhan.

\section{Biotitization-Silicification}

This type of metasomatism is widespread particularly in andesitic rock types, which lie near the intrusive granites. The typical reaction includes replacement of feldspar by biotite/or sericite and sometimes plagioclase by potash feldspar. The presence of pseudomorphous replacement of the phenocrysts by shreddy biotite is diagnostic of potassium metasomatism. Biotite-quartz alterations of the lower andesites are characterized by LILE (K-Rb-Ba) and FTSM (Cr-Ni) enrichment and depletion in LREE, relative to the least-altered andesite (SIII.1). FTSM elements are accommodated in biotite crystals, while $\mathrm{K}-\mathrm{Rb}-\mathrm{Ba}$ elements are concentrated in biotite, sericite and orthoclase. The relative $\mathrm{Ca}$ and $\mathrm{P}$ depletion probably reflects the breakdown of apatite. The remaining elements exhibit minor dispersion, but appear to have remained relatively immobile. 


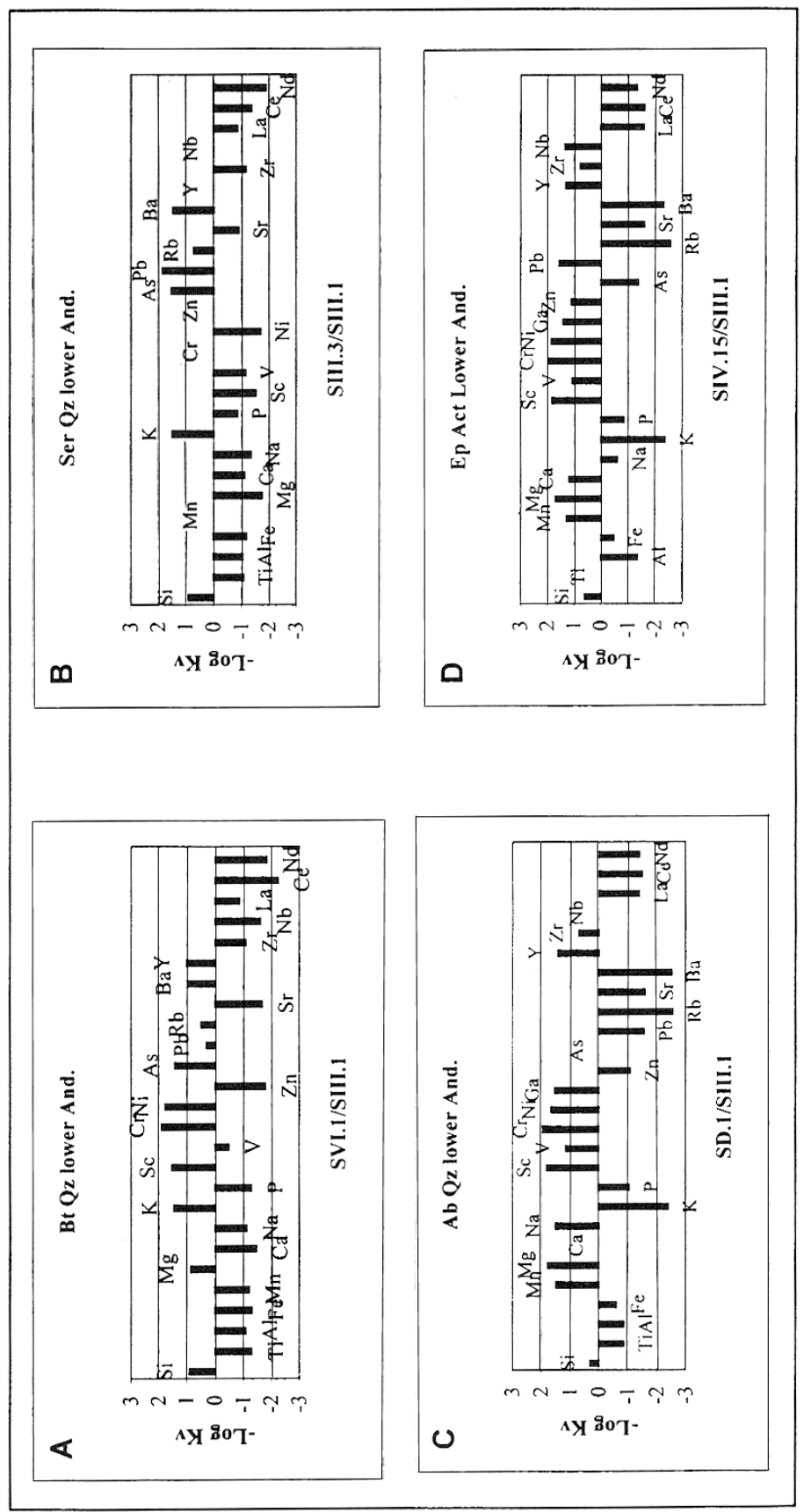

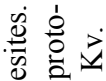

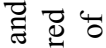

平产焉

$\Xi \underset{\mathscr{E}}{\Xi}$

品 $\cong$

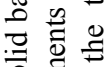

迎 气

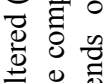

栗

密

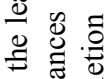

웡

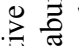

항

क

俤

寻

ग्ञ

ब.

旅

चี

웡

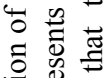

을 음

至

氙谣

.를.

टे थ

冚司

远 节

에릉

ज跣

है 恶

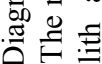

$\dot{\varphi}$ 


\section{Sericitization-Silicification}

Sericitization in the lower and upper volcanic sequences exhibit $\mathrm{K}-\mathrm{Rb}-\mathrm{Ba}$ enrichment and slight depletion in $\mathrm{Ca}$, Sr and LREE especially in the altered lower andesites, relative to the least-altered andesitic rocks (SIII.1 and MA.14 respectively). The large alkali elements are concentrated in sericite during the breakdown of feldspar, whereas divalent $\mathrm{Ca}$ and $\mathrm{Sr}$ are excluded. The sericitized andesites are enriched in Si relative to the fresh andesites, reflecting silicification (albitization?). The upper sericitized andesites show pronounced $\mathrm{Cu}-$ $\mathrm{Pb}$ enrichment, relative to the least-altered andesite (MA.14). The remaining elements exhibit minor deviation and behave as immobile elements.

\section{Albitization-Silicification}

The albite-quartz alteration is characterized by $\mathrm{Na}$ enrichment and slight depletion in LILE (K-Rb-Sr-Ba) relative to the least-altered andesites. During albitization of feldspar, $\mathrm{Na}$ is retained in albite, but LIL elements are excluded during devitrification of volcanic glass and its alteration products which contain these elements. In many instances, devitrification of acidic glasses, particularly when induced by hydrothermal solutions, leads to major changes in the total rock composition, affecting the glass as well as the crystalline phases of the rock. The general trend is a metasomatic replacement of $\mathrm{Na}$ by $\mathrm{K}$, an addition of $\mathrm{Si}$ and $\mathrm{H}_{2} \mathrm{O}$, and more rarely, of small amount of $\mathrm{Al}$ as well as an increase in the $\mathrm{Fe}^{3+} / \mathrm{Fe}^{2+}$ ratio (Ewart, 1971). The lower albitized andesites exhibit enrichment in FTSM elements which are accommodated in the chloritized clinopyroxene. With the exception of minor P, the remaining HFSE are immobile. Those liberated during the breakdown of the igneous assemblages (and/or lower grade precursors) are accommodated in the alteration assemblages.

\section{Epidotization-Chloritization}

The epidote-chlorite-quartz alteration of the two andesitic sequences is characterized by mild $\mathrm{Ca}$ enrichment and strong depletion in LILE (K-Rb-Sr-Ba) relative to the least altered andesites. The lower epidotized andesites exhibit strong enrichment in FTSM elements (Mn-Mg-Sc-Cr-Ni) which are accommodated in chlorite, while $\mathrm{Ca}$ is accommodated in epidote. The LIL elements are expelled, probably reflecting the breakdown of volcanic glass and its alteration products. The remaining elements show minor dispersion behaving as immobile elements.

\section{Chloritization}

The chlorite alteration is characterized by strong enrichment in FTSM elements and slight depletion in P, LILE and LREE, relative to the least altered andesite (SIII.1). FTSM enrichment reflects complete replacement of pyroxene by chlorite and epidote which accommodates these elements. 


\section{Composition-Volume Computations}

The observed major and trace element concentrations in the alteration products are mainly controlled by chemical properties of the precipitates. Many geochemical studies have demonstrated the mobility of major and trace elements during hydrothermal alteration. Such processes are controlled by pressure, temperature, fluid composition, waterrock ratio and time (Lesher et al. 1986). Several geochemical studies (Condie et al. 1977) have demonstrated the mobility of the large ion lithophile elements (LILE). In contrast, HFSE are potentially much less mobile. On the other hand, Ludden et al. (1982) and Nystrom (1984) demonstrated the potential mobility of the light rare earth elements (LREE) during extreme epidotization and carbontization. $\mathrm{P}$ and $\mathrm{U}^{+6}$ are also potentially mobile. They have high ionic potentials and may be soluble as complex anions in the hydrothermal fluids (Mason, 1966). The first transition series metals (FTSM: Sc through $\mathrm{Cr}$, Mn through $\mathrm{Zn}$ ) have different crystallographic site preference energies and may exhibit several valencies, so that their geochemical behavior is somewhat less predictable. Their mobility is largely dependent on the stability of the mafic silicate phases which contain them.

To evaluate major and trace element mobilities in the studied altered volcanic rocks and place-constraints on volume change during such alteration, composition-volume calculations are performed following the methods of Gresens (1967) and Avison (1985). Gresens (1967) derived equations, which were later modified by Babcock (1973), to express the chemical relationship between the whole-rock composition of metasomatic rocks and a parental or initial rock composition (assumed protolith), quantifying the actual exchange of material between parent and product rocks. Gresen's basic argument is that some components are likely to have been immobile in the alteration process, and that if these components can be identified, they can be used to establish any volume change which has taken place. Gains or losses of other components can then be calculated assuming that the volume change is a factor common to the behavior of all components. Gresens general equation can be expressed as follows:

$$
a\left\{K_{V}\left(P^{B} / P^{A}\right) X_{n}^{B}-X_{n}^{A}\right\}-\Delta X_{n}=0
$$

Where $K_{V}$ is the ratio between rock $A$ volume to that of rock $B ; P^{A}$ and $P^{B}$ are the rock densities, $X_{n}^{A}$ and $X_{n}^{B}$ are the weight fractions of element $n$, and $\Delta X_{n}$ is the absolute mass flux of $n$ between rocks $B$ and $A$. At constant volume $\left(K_{V}=1\right)$ :

$$
\Delta X_{n}=\left\{X_{n}^{B}\left(P^{B} / P^{A}\right)-X_{n}^{A}\right\}
$$

and for constant mass $\left(\Delta X_{n}=0\right)$ :

$$
K_{V}=\left\{X_{n}^{A} P^{A} / X_{n}^{B} P^{B}\right\}
$$


Avison (1985) suggested that the numerical magnitude of $\Delta X_{n}$ is not directly comparable with that for other rock components. Such relationships can be clarified if the values of $\Delta X_{n}$ are normalized relative to the original parent rock content of each component $\mathrm{n}$, so that:

$$
\Delta F^{n}=\Delta X_{n} / X_{n}^{A}
$$

Using the known compositions and densities of the rocks (Table 1), solutions to Eqn. (1) are linear functions of $\Delta X_{n}$ and $K_{V}$. Graphical analysis (Fig. 3 in Gresens, 1967) of composition-volume relationships between the least-altered andesite (assumed protolith) and the altered andesites and associated andesitic rocks indicates that the HREE and most HFS elements have been relatively immobile. The linear solutions to Eqn. (1) intersect in clusters corresponding to negligible mass changes within a very limited range of volume factors. Thus, the composition-volume relationships can be mathematically calculated (Table 2) and graphically illustrated on simple enrichment-depletion diagrams following the method of Lesher et al. (1986). In this method, the degree of enrichment/depletion is represented by $K_{V}$ for $\Delta X_{n}=0$ (Fig. 3). Propagation of sampling and analytical uncertainties in the calculations result in dispersion in $K_{V}$ for most elements. The assessment of the composition-volume change can be detected if certain elements have a constancy values of $K_{V}$ and $\Delta F^{n}$ which can be interpreted that those elements have remained relatively immobile (Gresens, 1967 and Campbell et al. 1984). The value of the composition-volume computations is revealed from Fig. (3) and Table (2) using equations (3) and (4) when performed on the bulk analysis of the least-altered andesites and different alteration facies of propylitic andesites. The indicated volume factors $\left(\log K_{V}\right)$ for altered rock types range from 1.00 to 1.39 for SIII.3 and SVI.3, through \pm 0.7 for SD. 1 and SIV.15 and, to -1.39 for SF.1 (Fig.3 A, B, C, D, E and Table 2). These correspond to volume increase up to 10 and $25 \%$ in sericitized and biotitized-silicified andesites respectively, conservation of volume in albitizedepidotized-silicified andesites and volume decrease up to $25 \%$ in chloritized andesite. Concerning the upper andesites, the indicated volume factors extend from 1.00 through 1.17 to 1.30 for MA.16, MIV.8 and MA.4 (Fig.3 F, G, H and Table 2). These reflect volume increase of up to 10,15 and $20 \%$ in sericitized, albitized and epidotized-silicified andesites respectively. The similarity of some major and HFS element ratios in the entire suites and the similarity of HFS element abundance in the least-altered andesites (SIII. and MA.14) and the most altered rock samples confirm that the use of SIII.1 and MA.14 as the least altered rock types is justified. Thus, elements which preserve interelement ratios have probably remained relatively immobile. 


\begin{tabular}{|c|c|c|c|}
\hline & 피 & 过 & 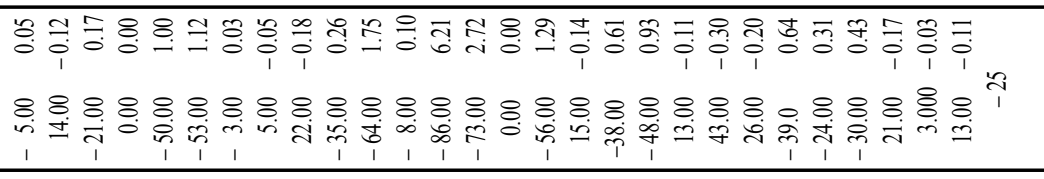 \\
\hline 5 & 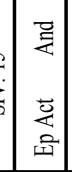 & $\vec{x}$ & 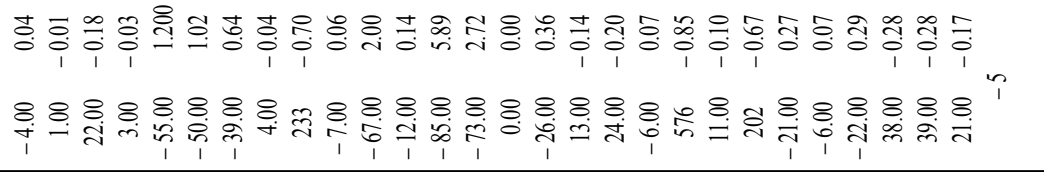 \\
\hline 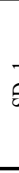 & \begin{tabular}{l}
2 \\
$\alpha$ \\
\multirow{2}{*}{}
\end{tabular} & 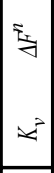 & 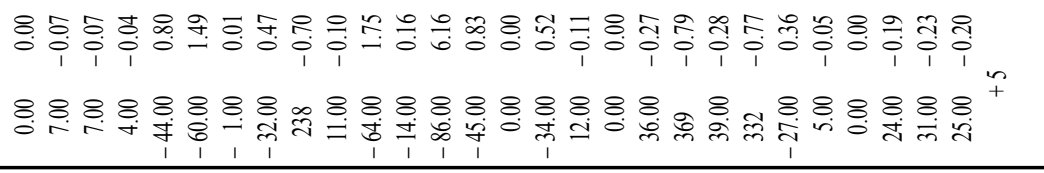 \\
\hline & 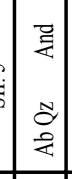 & 过 & 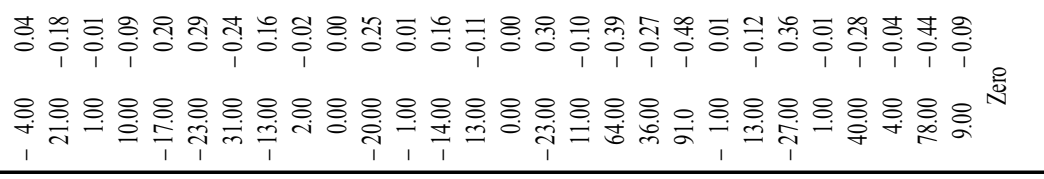 \\
\hline & $\begin{array}{l}2 \\
2 \\
\dot{2}\end{array}$ & $x^{2}$ & 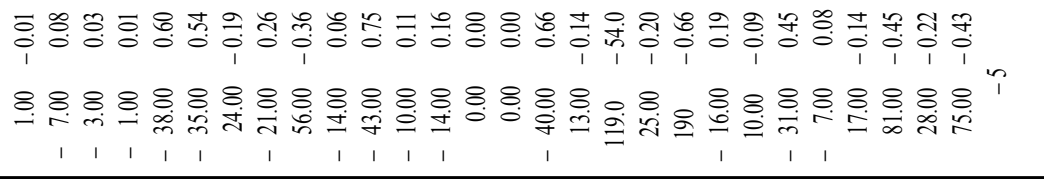 \\
\hline & 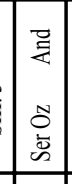 & 等 & 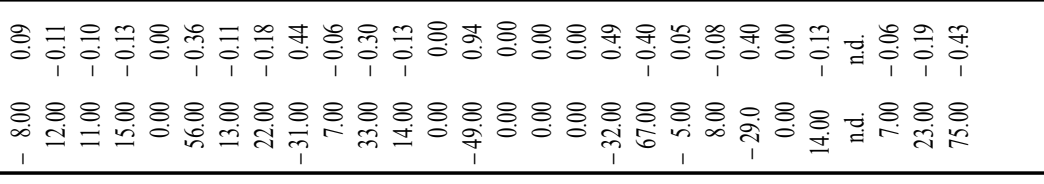 \\
\hline & 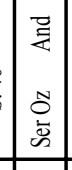 & 安 & 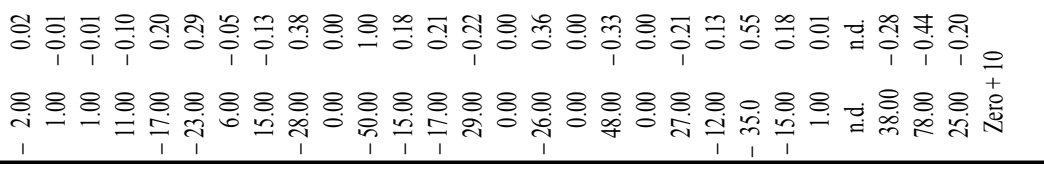 \\
\hline 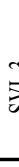 & 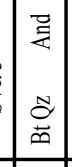 & 等 & 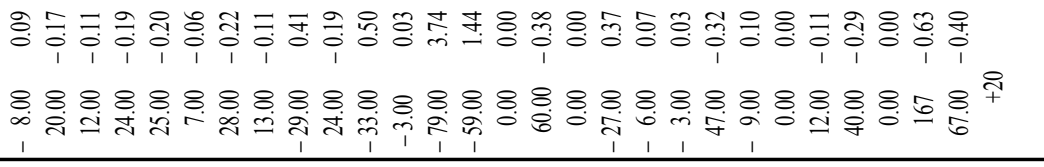 \\
\hline & 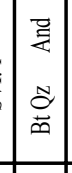 & $\therefore$ & 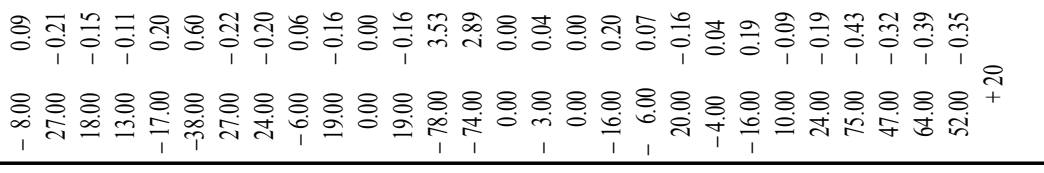 \\
\hline & 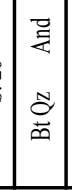 & $\underbrace{2}$ & 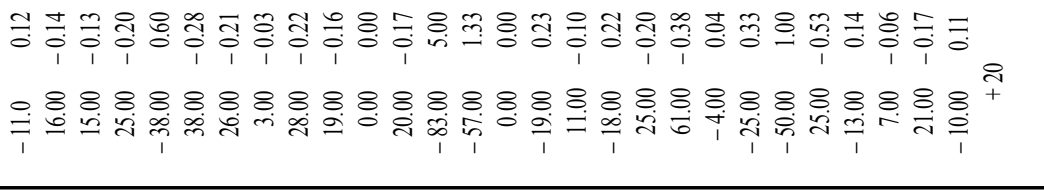 \\
\hline & 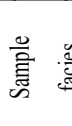 & & 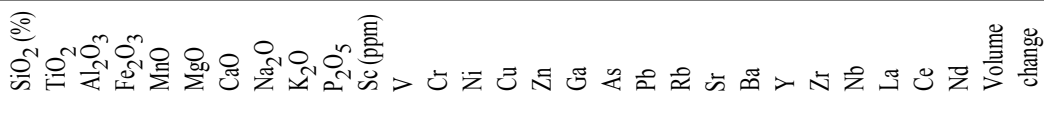 \\
\hline
\end{tabular}




\begin{tabular}{|c|c|c|c|}
\hline$\stackrel{\text { ঙ }}{\stackrel{i}{\Sigma}}$ & 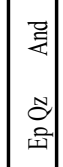 & $x^{2}$ & 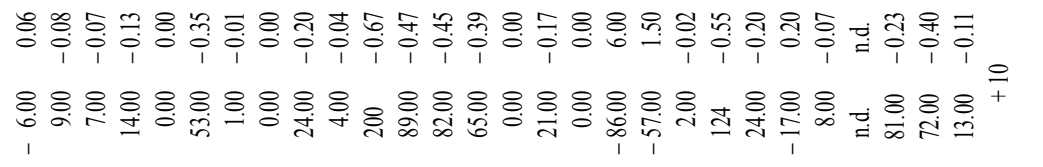 \\
\hline $\begin{array}{l}\stackrel{0}{\Sigma} \\
\dot{\Sigma}\end{array}$ & 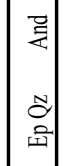 & $x^{2}$ & 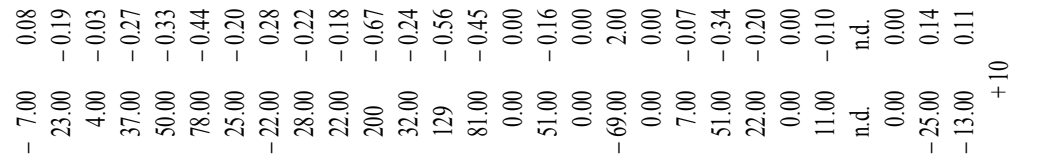 \\
\hline$\stackrel{+}{\grave{\Sigma}}$ & 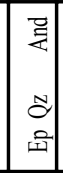 & $x^{2}$ & 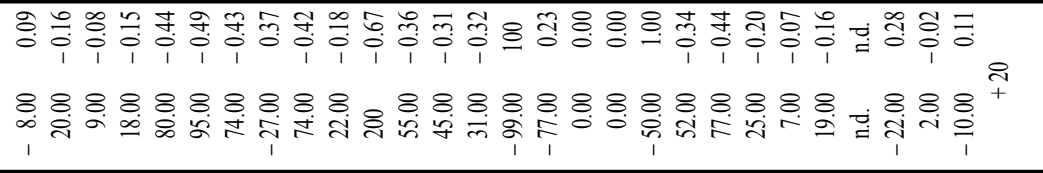 \\
\hline$=$ & 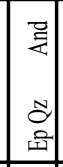 & i & 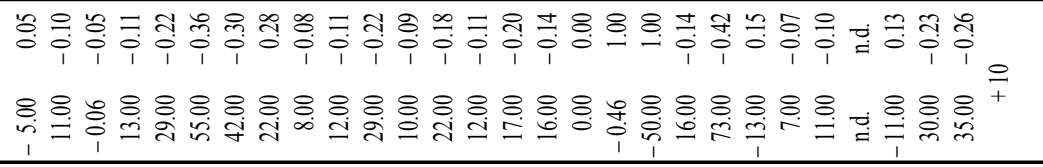 \\
\hline$=$ & 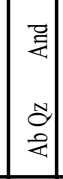 & $x^{2}$ & 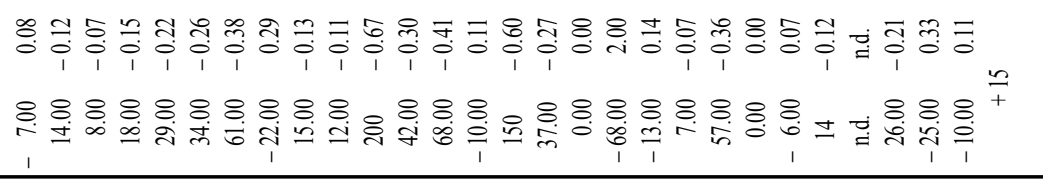 \\
\hline $\begin{array}{l}\infty \\
\sum\end{array}$ & $\begin{array}{l}0 \\
0 \\
0 \\
0\end{array}$ & 讨 & 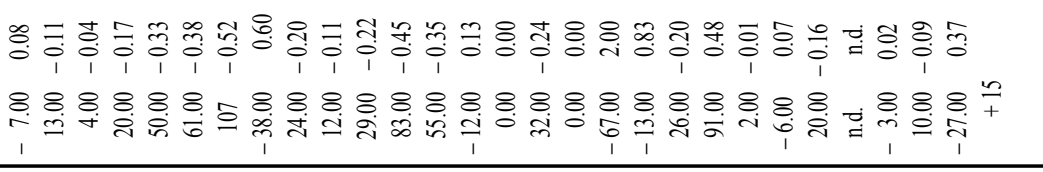 \\
\hline $\begin{array}{l}\simeq 1 \\
\dot{\sum}\end{array}$ & \begin{tabular}{l|l} 
\\
0 \\
0 \\
\end{tabular} & $\approx$ & 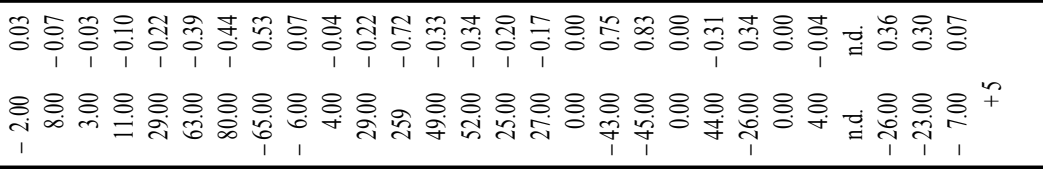 \\
\hline 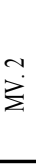 & 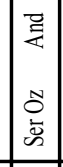 & $\approx$ & 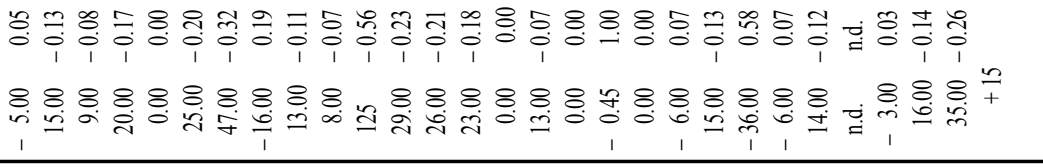 \\
\hline 宸 & 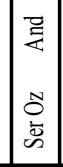 & 访 & 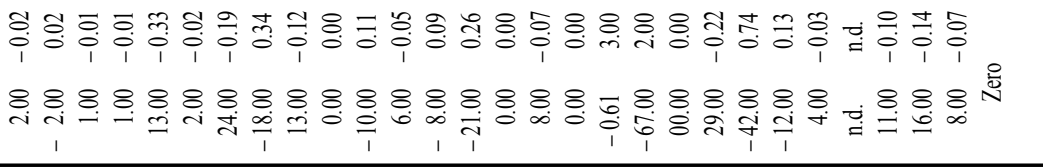 \\
\hline 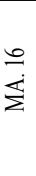 & 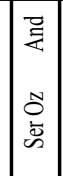 & $\approx$ & 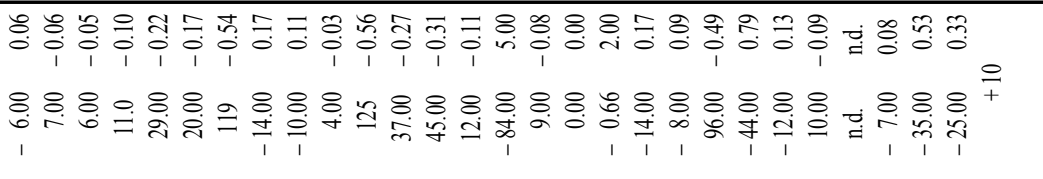 \\
\hline \multicolumn{3}{|c|}{ 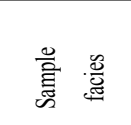 } & 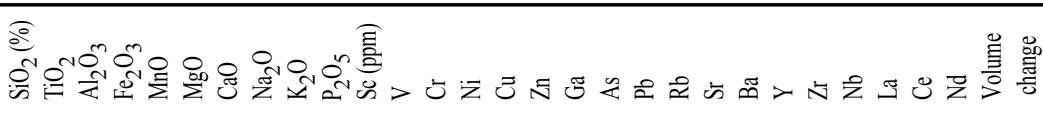 \\
\hline
\end{tabular}




\section{Discussion}

The geological interpretations of composition and volume changes in the studied altered volcanic rocks are impeded by several uncertainties. First, the present metamorphic mineral assemblages are not necessarily those of the original alteration assemblage. Second, the hydrothermal alteration probably occurred under varying physiochemical conditions during the dynamic evolution of the volcanic pile and the geothermal system, resulting in continuous and superimposed alteration. Third, the REE behavior in hydrothermal system is very complex, and there appear to be no simple rule applicable to the wide range of geological hydrothermal situations (Lesher et al. 1986 and Terakado and Fujitani, 1998). In spite of these limitations, the geological results can be made through comparison with the experimental studies and with mineral assemblages predicted by equilibrium thermodynamic calculations. The chlorite actinolite - albite - epidote - quartz - opaque minerals/sphene mineral assemblages of the altered volcanic rocks are typical of low grade, regionally metamorphosed mafic volcanic rocks (Jolly, 1980; and Gelinas et al. 1982). Similar mineral assemblages are forming in the basaltic and andesitic reservoir rocks in Icelandic high temperature (more than $200^{\circ} \mathrm{C}$ ) geothermal systems (Tomasson and Kristmannsdottir, 1972; and Kristmannsdottir, 1975).

\section{Silicification}

Silicification is a pronounced metasomatic alteration facies in the andesitic volcanics and results from the addition of silica. The concentration of dissolved $\mathrm{SiO}_{2}$ equals or exceeds quartz saturation in most experimental studies at 150 to $500^{\circ} \mathrm{C}$ (Mottl, 1983). Experimental studies of silica solubility in water (Kennedy, 1950) indicate that quartz solubility is strongly dependent on temperature at temperatures above the water-vapor critical point $\left(374^{\circ} \mathrm{C}, 218\right.$ bars). Only at temperatures less than about $350^{\circ} \mathrm{C}$ and at higher temperatures with pressures greater than 900 bars, quartz solubility decreases markedly with decreasing temperature. Accordingly, the silicification probably resulted from cooling of hydrothermal fluids that are initially less than $350^{\circ} \mathrm{C}$. With time and progressive silicification; permeability within the volcanic rocks would decrease (Facca and Tonai, 1967).

\section{Sericitization/potassium metasomatism}

Sericitization/potassium metasomatism is characterized by replacement of sodic and calcic phases by potassic phases. Exchange of $\mathrm{K}$ for $\mathrm{Na}$ and $\mathrm{Ca}$ may be accompanied by silicification, addition of $\mathrm{Cu}$ and hydration. All the authors attribute the chemical changes to potassium metasomatism by hydrothermal solution or vapors (Simons, 1962 and Macdonald, 1975). These observations 
agree with the experimental results. Truesdell (1966) showed by the membrane electrode method that the ion exchange between silicic glasses and dilute aqueous solutions is highly selective with a selectivity sequence $2 \mathrm{H}^{+}>2 \mathrm{~K}^{+}>2 \mathrm{Na}^{+}>$ $\mathrm{Ca}^{2+}>\mathrm{Mg}^{2+}$. If the hydrothermal solutions are acidic, alkalis are leached and the altered nature of the rocks is, in most cases, readily recognized by the presence of clay minerals, zeolites, or alunite and the dissolution of feldspar (Agron and Bentor, 1981). Alteration by alkaline solutions, however, frequently leaves no obvious indications and the rocks are entirely fresh looking as are those of Gabal El Dokhan area. Na mobility appears to be dependent primarily on the effective water/rock ratio, while, experimental studies indicate that $\mathrm{K}$ mobility is dependent primarily on temperature. $\mathrm{K}$ is leached from basalt at high temperature (more than $150^{\circ} \mathrm{C}$ ) (Bischoff and Dickson, 1975; Mottl and Holland, 1978 and Menzies and Seyfried, 1979) but removed from solution at lower temperature (Seyfried and Bischoff, 1979). This suggests that sericitization/ potassium metasomatism of the altered volcanics is a late stage and probably occurred at water/rock ratios more than 10 and lower temperature (less than $150^{\circ} \mathrm{C}$ ) during waning the hydrothermal activity.

\section{Albitization}

Albitization usually accompanies epidotization or chloritization in the volcanic sequences. Characteristic mineralogical changes in highly altered rocks include replacement of calcic plagioclase by sodic plagioclase and mafic minerals by chlorite and actinolitic amphibole, followed by prominent epidote. $\mathrm{Na}$ and $\mathrm{Na}-\mathrm{Ca}$ metasomatism are characterized by exchange of $\mathrm{Na}$ for $\mathrm{Ca}$ or $\mathrm{K}$ and secondarily by $\mathrm{Ca}$ for $\mathrm{Fe}$ and $\mathrm{Mg}$. They grade into calcic alteration in some rock varieties. Na-exchange at high temperatures (more than $150^{\circ} \mathrm{C}$ ) is influenced primarily by the effective water/rock mass ratio (Seyfried and Bischoff, 1979). $\mathrm{Na}$ is leached from basalt and enriched in solution at water/rock ratios more than 10, whereas $\mathrm{Na}$ is removed from water and fixed in basalt (Mottl and Holland, 1978) at water/rock ratios less than 5. Rosenbauer et al. (1988) also suggest that excess silica, high $\mathrm{Na} / \mathrm{Ca}$ ratio and low $\mathrm{Mg}$ content in the fluid are required to form these types during deep circulation of seawater. In any case, the formation of albite and epidote-rich alteration assemblages in volcanic sequences requires an evolved Mg-depleted fluid. This is probably water, modified by reaction with mafic or felsic volcanics lower in the stratigraphic sequence, or by mixing with magmatic fluids from subvolcanic magma chamber (Campbell et al. 1981). The appearance of epidote and disappearance of albite is interpreted to reflect decreasing $\mathrm{Na} / \mathrm{Ca}$ ratio and increasing temperature and pressure of the hydrothermal fluid. 


\section{Chloritization}

Magnesium metasomatism results from exchange of $\mathrm{Mg}$ for $\mathrm{Fe}$ and $\mathrm{Ca}$ accompanied by hydration. Experimental and theoretical studies by Mottl (1983) and Reed (1983) indicate that chloritization may occur at all water/rock ratios, and that chlorite-quartz assemblages are dominant at high water/rock ratios (more than 50). Chloritization is also characterized by LREE depletion. LREE fractionation has been reported in chloritized felsic volcanics by Baker and Degroot (1983) and Campbell et al. (1984). The LREE fractionation accompanying chloritization probably reflects the breakdown of LREE-enriched accessory phases (Clark, 1984). The sympathetic depletion of P-LREE in the chloritized andesitic rocks suggests that breakdown of apatite is responsible for the mobility of these elements.

\section{Conclusion}

In conclusion, the classification of metasomatic rocks in Table (3) has been prepared together with a qualitative assessment of the probable nature of the metasomatising fluid by employing the calculated data Table (2) $K_{V}$ and $\Delta F^{n}$ values along with petrographic descriptions.

The present study revealed the relative mobilities of many of the major and trace elements (summarized in Table 4) during metasomatism and lowgreenschist metamorphism together with their probable controlling phases. It is clear from Table (4) that $\mathrm{Ti}, \mathrm{Al}, \mathrm{Fe}, \mathrm{P}, \mathrm{Zr}$ and $\mathrm{Nb}$ coupled with $\mathrm{P} / \mathrm{Zr}, \mathrm{Ti} / \mathrm{Zr}$ and $\mathrm{Al} / \mathrm{Zr}$ display minor dispersion and behave as immobile elements. The immobile characters of these elements are well illustrated through their nearly constant values of $K_{V}$ and $\Delta F^{n}$. On the other hand, the Mg, FTSM, LILE (K-Rb$\mathrm{Ba}-\mathrm{Sr}-\mathrm{Ca}$ ) form a predictable group of elements which along with LREE and occasionally $\mathrm{Y}$ exhibit an organized pattern of mobility. This study has illustrated the potential of composition-volume computations and their superiority over conventional binary element plots, in characterizing metasomatism at a semiquantitative level.

\section{Summary}

Five alteration facies at Gabal El Dokhan area have been recognized based on the mineralogy and geochemistry, namely biotitization-silicification, sericitization-silicification, albitization-silicification, epidotization-silicification and chloritization. Some of the chemical modifications are very similar to those observed in hydrothermal altered volcanic rocks elsewhere in the world, or produced in experimental studies and predicted by theoretical models. 
Relative to the least altered andesite (assumed protolith), the biotitizedsilicified andesites are enriched in K-Rb-Ba-FTSM and depleted in LREE. The elements like Ti, Al, $\mathrm{P}$ and HFSE particularly $\mathrm{Zr}$ are immobile and retain their original abundances which indicate volume increase up to 25 percent. The sericitized-silicified andesites are strongly enriched in $\mathrm{K}-\mathrm{Rb}-\mathrm{Ba}$ and slightly depleted in Ca-Sr-FTSM, whereas the albitized-silicified andesites are enriched in $\mathrm{Na}$ and depleted in LILE and LREE. The immobile elements which have constants values of $\mathrm{K}_{\mathrm{V}}$ and $\Delta \mathrm{F}^{\mathrm{n}}$ indicate that volume change shows minor variations (zero/ +15 percent) during sericitization, but it exhibits moderate dispersion $(-5 /+15$ percent) during albitization. Concerning the altered upper andesites, the immobile elements show volume increase up to 15 percent during both the sericitization and albitization. The epidotized lower andesite is enriched in Ca-FTSM and depleted in LILE and LREE accompanied minor volume loss up to 5 percent, but the epidotized-silicified upper andesites are enriched in $\mathrm{Na}-\mathrm{Ca}-\mathrm{Cu}-\mathrm{Pb}$ and depleted in P-FTSM and LILE accompanied volume increase up to 20 percent. The chloritized lower andesite is strongly enriched in Mg-FTSM and depleted in K-Rb-Ba and LREE with volume decrease up to 25 percent.

Silicification is a widespread alteration facies that characterizes lower and upper andesites and probably resulted from cooling of hydrothermal fluids at water/rock ratios $<50$ and lower temperatures $\left(250-350^{\circ} \mathrm{C}\right)$. Sericitization probably occurred at water/rock ratio more than 10 and lower temperatures (less than $150^{\circ} \mathrm{C}$ ) during waning hydrothermal activity, whereas albitization occurred as the result of excess silica, high $\mathrm{Na} / \mathrm{Ca}$ and low $\mathrm{Mg}$ content. Appearance of epidote and disappearance of albite reflects decreasing $\mathrm{Na} / \mathrm{Ca}$ ratio, and increasing temperature and pressure of the hydrothermal fluid. Chloritization is primarily a product of water-rock interaction at high water/rock ratios (probably more than 50).

\section{Acknowledgement}

The author thanks Prof. Andersen and Prof. Rollinson for their valuable suggestions and careful reading of the manuscript. Also, he gratefully acknowledges Prof. El-Bouseily for his advices and constructive criticism of this work.

\section{References}

Agron, N. and Bentor, Y.K. (1981) The volcanic massif of BiQ'at Hayareah (Sinai-Negev): A case of potassium metasomatism. J. Geol. 89: 479-494 .

Akaad, M.K. and Noweir, A.M. (1969) Lithostratigraphy of the Hammamat-Umm Seleimat district, Eastern Desert, Egypt. Nature 503: 284-285.

Avison, M. (1985) Metasomatism in the lough Guitane volcanic complex, south west Ireland- an application of composition-volume computation. Chem.Geol. 48: 79-92. 
Babcock, R. S. (1973) Computational models of metasomatic processes. Lithos 6: 279-290.

Baker, J. H. and Degroot, P. A. (1983) Proterozoic seawater-felsic volcanics interaction. West Bernslagen, Sweden. Evidence for high REE mobility and implications for 1.8G seawater compositions. Contrib. Mineral. Petrol. 82: 119-130.

Basta, E.Z., Kamel, O.A. and Awadallah, M.F. (1979) Petrography of the Gabal El Dokhan volcanics, Eastern Desert, Egypt. Annals Geol. Surv. of Egypt 22: 145-171.

Bischoff, J. L. and Dickson, F.W. (1975) Seawater-basalt interaction at $200^{\circ} \mathrm{C}$ and 500 bars: Implications for origin of sea-floor heavy metal deposits and regulation of seawater chemistry. Earth Planetary Science Letters 25: 385-379.

Bogolepov, V. G.(1963) The recomputation of the chemical analyses of rocks in studying metasomatic processes. International Geol. Review 1962, 5(15): 1585-1592.

Campbell, I. H., Franklin, J. M., Gorton, M.P., Hart, T.R. and Scott, S. D. (1981) The role of subvolcanic sills in the generation of massive sulfide deposits. Econ.Geol. 76: 2248-2253.

Campbell, I.H., Lesher, C.M., Coad, P., Franklin, J.M., Gorton, M.P. and Thurston, P.C. (1984) Rare-earth element mobility in alteration pipes below massive $\mathrm{Cu}-\mathrm{Zn}$ sulfide deposits. Chem. Geol. 45: 181-202.

Clark, A.M. (1984) Mineralogy of the rare earth elements. In: Rare Earth Geochemistry (Edited by Henderson) Chapt. 2: 33-61.

Condie, K.C., Viljoen, M.J. and Kable, E. J. D. (1977) Effects of alteration on element distributions in Archean tholeiites from the Barberton greenstone belts, south Africa. Contrib. Mineral. Petrol. 64: 75-89.

Condie, K.C. (1981) Archean Greenstone Belts. 434P. Elsevier, Amsterdam.

El-Ramly, M.F. (1972) A new geological map of the basement rocks in the Eastern and Southwestern part of Egypt, scale 1: 1.000.000. Annals Geol. Surv. of Egypt 11: 1-18.

Ewart, A. (1971) Chemical changes accompanying spherulitic crystallization in rhyolitic lavas, central volcanic region, New Zealand. Mineral. Mag. 38: 424-434.

Facca, G. and Tonai, F. (1967) The self-sealing geothermal field. Bull. of Volcanol. 30: 271-273.

Gelinas, L., Mellinger, M. and Trudel, P. (1982) Archean mafic metavolcanics from RouynNoranda district, Abitibi; Greenstone Belt, Quebec. 1. Mobility of the major elements. Canad. J. of Earth Science 19: 2258-2275.

Ghobrial, M.G. and Lotfi, M. (1967) The geology of Gabal Gattar and Gabal El Dokhan area. Annals Geol. Surv. of Egypt 40: 26p.

Gibson, H.L., Watkinson, D. H. and Comba, C.D.A. (1983) Silicification. Hydrothermal alteration in an Archean geothermal system within the Amulet "Rhyolite Formation" Noranda, Quebec. Econ. Geol. 78: 954-971.

Grant, J. A. (1986) The Isocon Diagram. A simple solution to Gresen's Equation for metasomatic alteration. Econ. Geol. 81: 1976-1982.

Gresens, R. L. (1967) Composition-volume relationships of metasomatism.Chem.Geol. 2: 47-65.

Irvine, T. N. and Baragar, W. R. A. (1971) A guide to the chemical classification of the common volcanic rocks. Canad. J. of Earth Science 8: 523-548.

Jolly, W. T. (1980) Development and degradation of Archean lavas, Abitibi area, Canada in light of major element geochemistry. J. of Petrol. 21: 323-363.

Kennedy, G. C. (1950) A portion of the system silica-water. Econ. Geol. 45: 629-653.

Khalaf, E.D.H. (1994) Petrography, Geochemistry and Petrogenesis of volcanics and associated rocks of Gabal EL Dokhan area, Northeastern Desert, Egypt. Ph.D. dissertation 172 p. Cairo University.

Kristmannsdottir, H. (1975) Hydrothermal alteration of basaltic rocks in Iceland geothermal areas. Second U.N. symposium on the development and utilization of geothermal resources, proceedings, pp. 441-445. 
Lesher, C.M., Gibson, H.L. and Campbell, I.H. (1986) Composition-volume changes during hydrothermal alteration of andesites at Buttercup Hill, Noranda District, Quebec. Geochimica et Cosmochimica Act. 50: 2693-2705.

Ludden, J. N., Gelinas, L. and Trudel, P. (1982) Archean metavolcanics from the RouynNoranda district, Abitibi Greenstone Belt. 2. Mobility of trace elements and petrogenetic constraints. Canad. J. of Earth Science Letters 19: 2276-2287.

Macdonald, R. (1975) Nomenclature and petrochemistry of the peralkaline oversaturated extrusive rocks. Bull. of Volcanol. 38: 498-516.

Mason, B. (1966) Principles of Geochemistry. 329 p. Wiley, New York.

Menzies, M. and Seyfried, W. E. IR. (1979) Basalt-seawater interaction: Trace element and strontium isotopic variations in experimentally altered glassy basalt. Earth Planetary Science Letters 44: 463-472.

Mottl, M.J. (1983) Metabasalts, axial hot springs and the structure of hydrothermal system at mid-ocean ridge. Geological Society of American Bull. 94: 161-180.

Mottl, M. J. and Holland, H.D. (1978) Chemical exchange during hydrothermal alteration of basalt by seawater- I. Experimental results for major and minor components of seawater. Geochimica et Cosmochim Acta 42: 1103-1115.

Nystrom, J.O. (1984) Rare earth element mobility in vesicular lava during low-grade metamorphism. Contrib. Mineral. Petrol. 8 : 328-331

Poldervaart, A. (1953) Petrological calculations in metasomatic processes. American J. of Science 251: 481-504.

Riverin, G. and Hodgson, C.J. (1980) Wall rock alteration at the Millenbach Cu-Zn Mine,Noranda, Quebec. Econ. Geol. 75: 424-444.

Rosenbauer, R.J., Bichoff, J. L. and Zierenberg, R.A. (1988) The laboratory albitization of mid-ocean ridge basalt. J. of Geol. 96: 237-244.

Seyfried, W. E. IR. and Bischoff, J. L. (1979) Low temperature basalt alteration by seawater : An experimental study at $70^{\circ} \mathrm{C}$ and $150^{\circ} \mathrm{C}$. Geochimica et Cosmochim Acta 43: 1937-1947.

Simons, F. S. (1962) Devitrification dikes and giant spheralites from Klondyke, Arizona. Amer. Mineral. 47: 871-885.

Terakado, Y. and Fujitani, T. (1998) Behaviour of the rare earth elements and other trace elements during interactions between acidic hydrothermal solutions and silicic volcanic rocks, Southwestern Japan. Geochimica et Cosmochim Acta 62: 1903-1917.

Tomasson, J. and Kristmannsdottir, H. (1972) High temperature alteration minerals and thermal brines, Reykjanes, Iceland. Contrib. Mineral. Petrol. 36: 123-134.

Truesdell, A. H. (1966) Ion exchange constants of natural glasses by the electrode method. Amer. Mineral. 51: 110-122.

Turner, F.J. and Verhoogen, J. (1960) Igneous and metamorphic petrology. 694P. McGrawhill, New York, N.Y. 


\begin{tabular}{|c|c|c|c|c|c|c|}
\hline 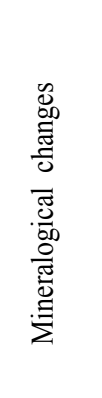 & & 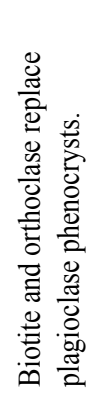 & 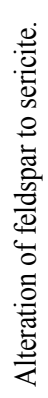 & 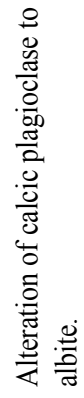 & 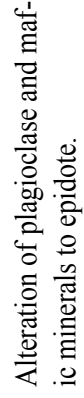 & 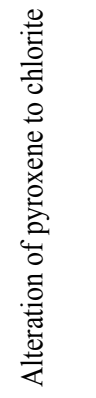 \\
\hline 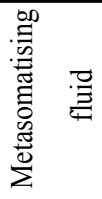 & & 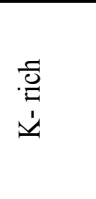 & $\begin{array}{l}\overline{\tilde{D}} \\
\dot{\Xi} \\
\dot{1}\end{array}$ & 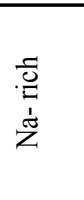 & 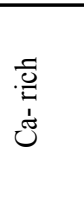 & 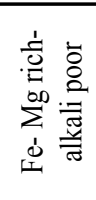 \\
\hline 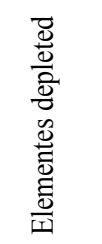 & & $\begin{array}{l}\text { 荇 } \\
\text { 밈 }\end{array}$ & 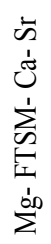 & 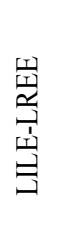 & 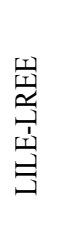 & 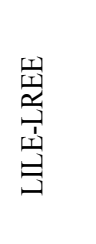 \\
\hline 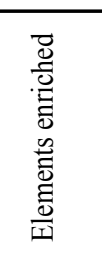 & & 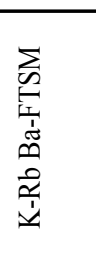 & 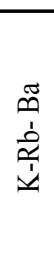 & $\tilde{z}$ & 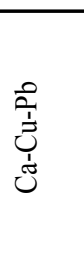 & 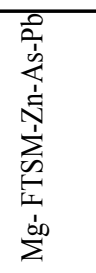 \\
\hline 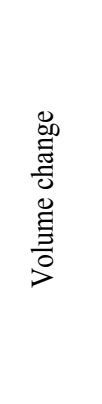 & 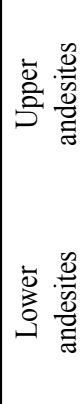 & $\begin{array}{l} \\
\\
\stackrel{0}{0} \\
\stackrel{1}{1} \\
+ \\
0 \\
\stackrel{0}{2} \\
\stackrel{1}{+} \\
+\end{array}$ & 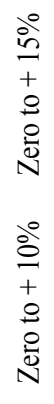 & $\begin{array}{l}\stackrel{0}{0} \\
i \\
+ \\
0 \\
i n \\
+ \\
\\
i n \\
+ \\
0 \\
0 \\
1\end{array}$ & $\begin{array}{l}\stackrel{0}{0} \\
+ \\
+ \\
0 \\
0 \\
+ \\
\\
\text { in } \\
1\end{array}$ & $\stackrel{\stackrel{\circ}{i}}{i}$ \\
\hline 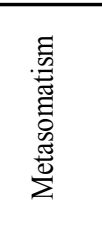 & & 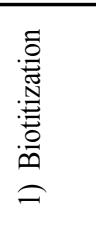 & 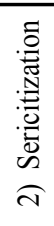 & 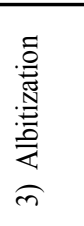 & 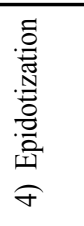 & 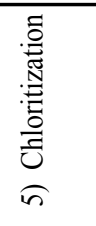 \\
\hline
\end{tabular}




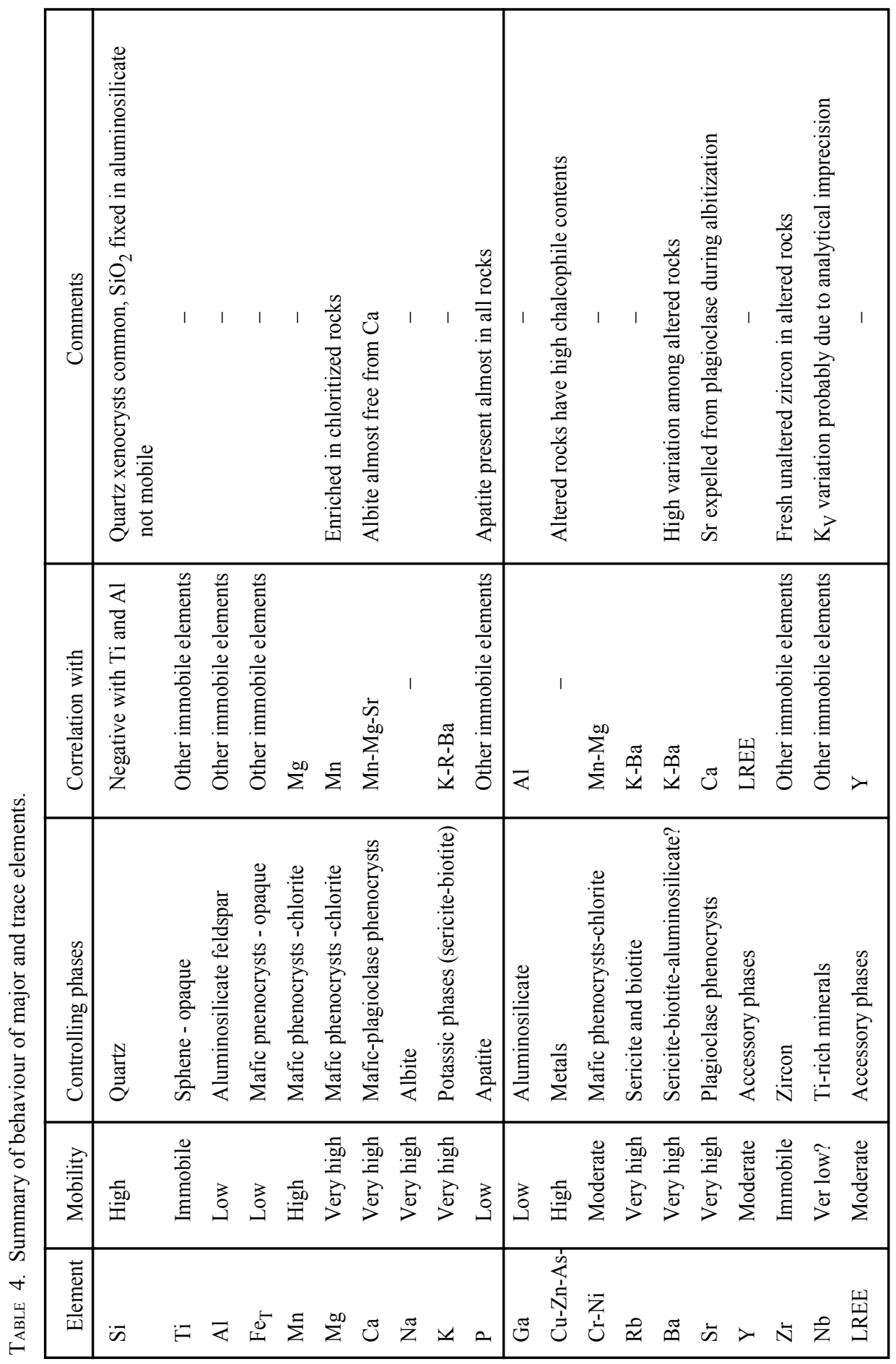




\title{
التغير الحجمي والتركيبي خلال تغير وتحول صخور الأنديزيت البركانية في منطقة جبل الدخان ، شمال الصحر اء الشرقية ، مصر
}

\author{
عز الدين عبد الحكيم خلف \\ قسم الجيولوجيا ، كلية العلوم ، جامعة القاهرة

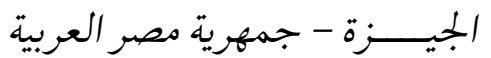

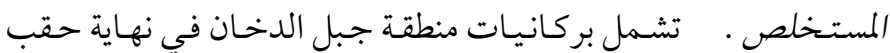

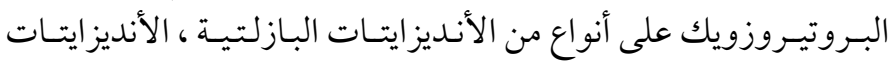

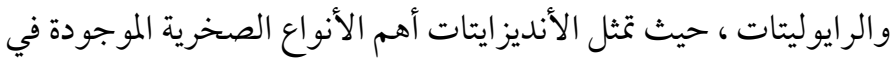

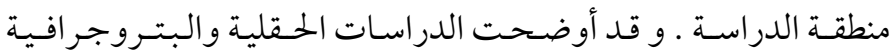

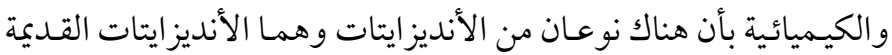

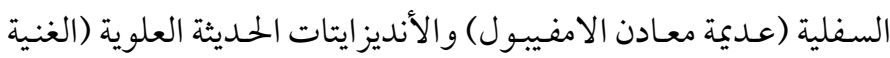

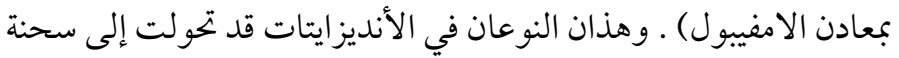

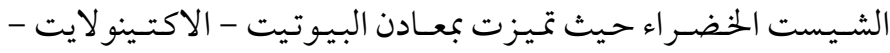

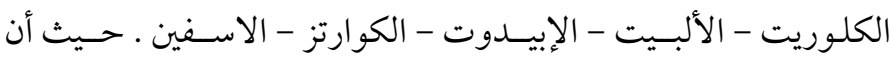

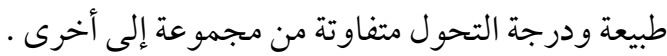

وقد أمكن تقسيم السحنات المتغيرة والمتحولة إلى خمسة أنواع : 1 - سحنة البيوتيت - كوارتز ، Y- سحنة السيروسايت - كوارتز ،

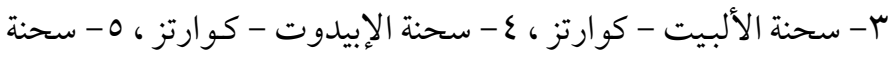

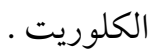

تتميز سحنة البيوتيت - كوارتز بالزيادة في العناصر الأرضية النادرة

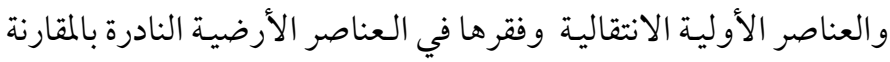

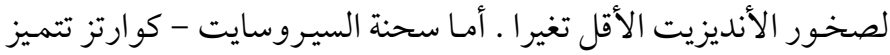

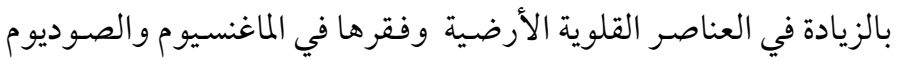

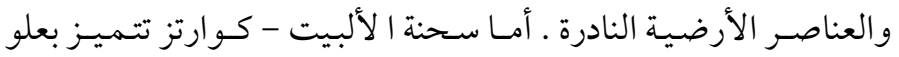

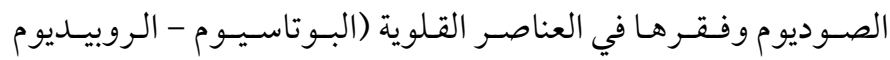


والباريوم) والعناصر الأرضية النادرة ـ تتميز سحنة الإبيدوت - كوارتز

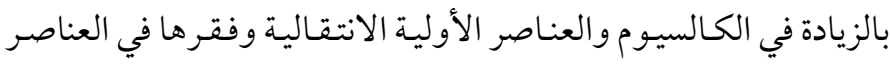

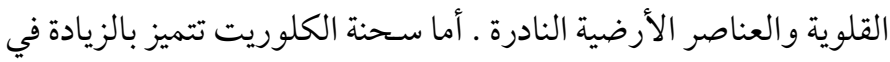

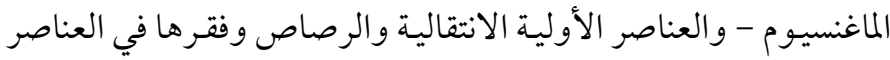
القلوية الأرضية ، و الفوسفور و الاسترنشيوم والعناصر الأرضية النادرة . ومن خلال هذه الدراسة وجد أن عناصر التيتانيوم والألمنيوم و الحديد

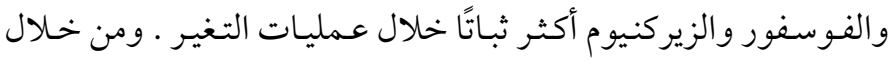

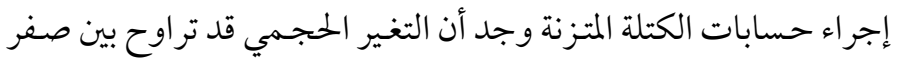

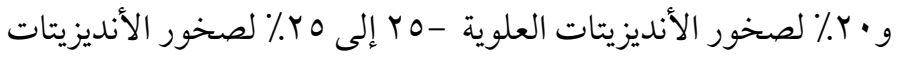

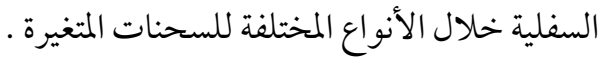

